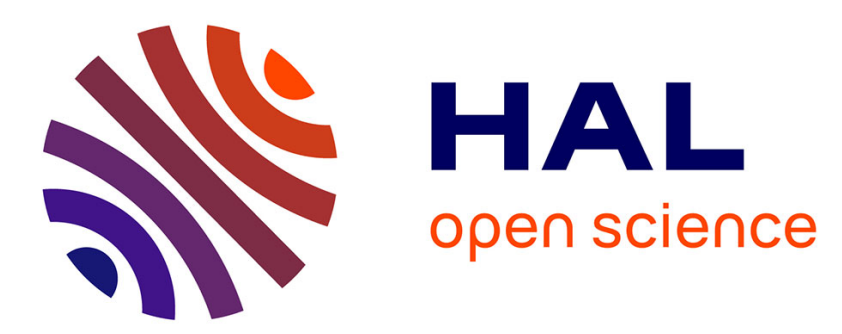

\title{
Physically based model of downstream fining in bedrock streams with lateral input
}

Phairot Chatanantavet, Eric Lajeunesse, Gary Parker, Luce Malverti, Patrick Meunier

\section{- To cite this version:}

Phairot Chatanantavet, Eric Lajeunesse, Gary Parker, Luce Malverti, Patrick Meunier. Physically based model of downstream fining in bedrock streams with lateral input. Water Resources Research, 2010, 46 (2), pp.W02518. 10.1029/2008WR007208 . insu-01288720

\section{HAL Id: insu-01288720 \\ https://hal-insu.archives-ouvertes.fr/insu-01288720}

Submitted on 15 Mar 2016

HAL is a multi-disciplinary open access archive for the deposit and dissemination of scientific research documents, whether they are published or not. The documents may come from teaching and research institutions in France or abroad, or from public or private research centers.
L'archive ouverte pluridisciplinaire HAL, est destinée au dépôt et à la diffusion de documents scientifiques de niveau recherche, publiés ou non, émanant des établissements d'enseignement et de recherche français ou étrangers, des laboratoires publics ou privés. 


\title{
Physically based model of downstream fining in bedrock streams with lateral input
}

\author{
Phairot Chatanantavet, ${ }^{1,2}$ Eric Lajeunesse, ${ }^{3}$ Gary Parker, ${ }^{4}$ Luce Malverti, ${ }^{3}$ \\ and Patrick Meunier 5 \\ Received 30 May 2008; revised 12 September 2009; accepted 28 September 2009; published 27 February 2010.
}

[1] Bed load particles in bedrock streams receiving lateral input from hillslopes may or may not show a clear, monotonic pattern of size reduction in the downstream direction. Both abrasion and selective sorting may play important roles in generating downstream fining. The objective of this study is to develop a physically based model of downstream fining in bedrock streams with lateral input based on both processes. A surface-based gravel transport relation for the size mixture is employed to account for the effect of selective sorting (differential transport). While the model produces silt and sand by abrasion, it is also assumed to loosely capture particle fracturing via a lumped abrasion coefficient embodied in Sternberg's law. The model is here tested against field data from Vieux Habitants River in Guadeloupe Island, which is located in the Caribbean Sea. The river shows clear downstream fining, and this pattern is captured reasonably well by the model. The model results indicate that abrasion (including fracturing) is solely responsible for the downstream fining pattern for most of the study reach of the Vieux Habitants River. Sensitivity analysis of the model has also been performed. The model results suggest that, in general, selective sorting by differential transport can play a role in downstream fining only in cases of streams with relatively fine gravel sizes and lower slopes. The results also indicate that abrasion (including fracturing) and selective sorting can be equally important for downstream fining in bedrock rivers. The results also suggest that future work should explicitly consider fracturing (comminution) separately from abrasion (wear) rather than lumping them in a Sternberg-type coefficient.

Citation: Chatanantavet, P., E. Lajeunesse, G. Parker, L. Malverti, and P. Meunier (2010), Physically based model of downstream fining in bedrock streams with lateral input, Water Resour. Res., 46, W02518, doi:10.1029/2008WR007208.

\section{Introduction}

[2] In the past few decades, many studies of changes in bed surface and bed load size distributions in gravel streams have focused on downstream fining [e.g., Knighton, 1984; Parker, 1991a, 1991b; Kodama, 1994a, 1994b; Hoey and Ferguson, 1994; Pizzuto, 1995; Seal and Paola, 1995; Ferguson et al., 1996; Gasparini et al., 1999]. Downstream decreases of the median grain size of bed material and bed load are attributed to selective sorting (in which smaller sizes are preferentially transported faster and farther downstream), abrasion (by which larger clasts are worn down to silt or sand), or both. Sklar et al. [2006] argued that in

\footnotetext{
${ }^{1}$ St. Anthony Falls Laboratory, Department of Civil Engineering, University of Minnesota, Minneapolis, Minnesota, USA.

${ }^{2}$ Now at School of Earth and Space Exploration, Arizona State University, Tempe, Arizona, USA.

${ }^{3}$ Laboratoire de Dynamique des Fluides Géologiques, Institut de Physique du Globe de Paris, Paris, France.

${ }^{4}$ Department of Civil and Environmental Engineering and Department of Geology, University of Illinois at Urbana-Champaign, Urbana, Illinois, USA. UK.

${ }^{5}$ Department of Earth Sciences, University of Cambridge, Cambridge,

Copyright 2010 by the American Geophysical Union. 0043-1397/10/2008WR007208\$09.00
}

bedrock streams where no net deposition occurs, abrasion alone should be responsible for downstream fining. Kodama [1994a] has similarly argued that in some typhoon-dominated streams abrasion may be dominant. Kodama has interpreted "abrasion" to include fracturing as well as wear. It has been alternatively argued that in cases with net deposition along the channel, selective sorting may often play the dominant role in downstream fining [e.g., Paola et al., 1992; Gomez et al., 2001].

[3] Selective sorting processes contributing to downstream fining can be classified into two types [e.g., Kodama, 1994a]: (1) differential transport, by which finer grains are preferentially transported downstream faster and farther than the coarser ones, and (2) selective entrainment or selective transport, in which only the fraction of the bed material smaller than a threshold size is transported by a given flow event. The former type of selective sorting has been modeled [e.g., Parker, 1991a, 1991b; Hoey and Ferguson, 1994; Cui et al., 1996] using gravel transport relations designed for mixtures [e.g., Parker, 1990].

[4] Rana et al. [1973] modeled downstream fining by selective transport in sand bed streams and found the rate of downstream fining to be independent of the total sediment load when various discharge-sediment concentration combinations were used. Parker [1991a, 1991b] was among the first to model downstream fining in gravel bed rivers; the 
model includes both selective sorting (through differential transport) and abrasion. He quantified the link between profile concavity and downstream fining. Several other studies have also yielded models for the routing of mixedsize sediments [e.g., Rahuel et al. 1989; Parker, 1990, 1991a; van Niekerk et al., 1992; Hoey and Ferguson, 1994; Gasparini et al., 2004]. Hoey and Ferguson [1994] further developed and extended the numerical model of Parker [1991a] by routing gravel-sized sediment along a channel that is free to adjust both its long profile and surface texture. They found that strong profile concavity can force rapid downstream fining, even when the bed load transport itself is only slightly size selective.

[5] Mathematical models focusing solely on the process of downstream fining within a channel with no lateral input either from hillslope or tributaries can be difficult to apply to field data. In most rivers, and in particular most mountain rivers, multiple lateral sources of sediment (such as gravel or boulders) are present. All rivers are part of channel networks, and any particular gravel bed river should have several sources of gravel from either upstream or lateral contributions. Each source could supply sediment of different sizes to the network. If a sample of grains is "followed" downstream, additional sediment would be supplied by tributaries and local lateral sources such as landslides. This sample of gravel would then be continually modified by these additions regardless of any particular downstream fining processes [Pizzuto, 1995].

[6] Relatively few researchers [e.g., Rice, 1994; Pizzuto, 1995; Sklar et al., 2006] have developed a network-based routing model to determine how spatial variations in sediment supply influence rates of downstream fining. Sklar et al. [2006] were among the first to study downstream fining in bedrock streams with lateral input. For the case of spatially uniform supply of poorly sorted hillslope materials, they found that abrasion of grain particles during fluvial transport in bedrock streams has a small effect on the bed load size distribution because local resupply offsets the size reduction from upstream. They then suggested that downstream fining must be due mainly to spatial gradients in hillslope sediment production (e.g., high lateral input upstream and low lateral input downstream). The model of Sklar et al. [2006], however, did not specifically consider selective sorting processes in downstream fining in bedrock streams. The present analysis indicates that selective sorting by differential transport can in some cases play a role when combined with abrasion or splitting.

[7] The present study focuses on developing a physically based model of downstream fining in bedrock streams with lateral input, which incorporates both abrasion and selective sorting. A surface-based gravel transport relation for size mixtures from Parker [1990] is employed here to account for the effect of selective sorting by differential transport. One of our goals here is to test whether and where selective sorting plays a role in downstream fining in bedrock streams.

[8] The model is applied to a fairly typical steep bedrock stream flowing into the ocean. More specifically, the model is tested against field data in Vieux Habitants River, an andesitic bedrock river flowing on the tropical volcanic Basse-Terre Island, which is a part of Guadeloupe Island (Guadeloupe archipelago, Lesser Antilles Arc). Our primary goal of testing the model with this field site is to see if the model results are consistent with our collected field data of surface mean grain size and field observation of the degree of bedrock exposure (qualitatively only). Sensitivity analysis of the model is also conducted and discussed.

[9] A secondary purpose of the present investigation is to test whether granulometric measurements of downstream fining along bedrock streams can be used to quantify longterm bed load transport. Indeed, bed load transport in rivers on Basse-Terre Island appears to be driven by flash floods triggered by episodic intense rainfalls during the rainy season. Direct measurement of bed load transport during these events is not possible, and their impact on long-term denudation rates has not yet been quantified. A physically based model of downstream fining constrained with both granulometric and hydrologic data could therefore provide an indirect estimate of bed load transport associated with intense flow rates.

[10] This paper starts with the model framework. Then a description of the field site and the procedure for data acquisition are discussed. The model application to the field data is then outlined, and the results and sensitivity analysis are evaluated and discussed.

\section{Model Development}

[11] This section presents the development of the theoretical model for downstream fining in bedrock streams with lateral input incorporating both abrasion and sorting due to selective transport and deposition.

\subsection{Assumptions}

[12] Key assumptions in the present study are as follows: (1) bedrock incision processes occur so slowly that the pattern of downstream fining can be treated as quasi-steady state; (2) all particle sizes (including big boulders) are moved during large floods when the ratio of shear stress to the reference (critical) stress becomes $>1$; (3) size reduction due to both fracturing and abrasion to silt or sand is treated implicitly within a single abrasion coefficient; (4) the denudation rate is assumed to be spatially constant throughout the drainage basin (an assumption that can easily be relaxed, as will be shown in some runs); and (5) only a single channel following Hack's [1957] law receiving lateral input from hillslopes is considered. The model can be extended to a distributed drainage network at a later time.

\subsection{Theoretical Development}

[13] In this section we describe the theoretical framework used in modeling downstream fining in bedrock streams with lateral input from hillslopes. We start from descriptions of the abrasion coefficient and its relation to Sternberg's [1875] law, concepts related to probability density functions used in the model, and theoretical consideration of abrasion and mass transfer processes in bedrock streams. Then we consider mass conservation of bed sediment for gravel-size mixtures, using appropriate quantifications of abrasion and volume transfer, and derive governing differential equations for downstream fining in bedrock streams with lateral input. We then also list other related equations used in the model such as the width-area relation, Hack's law, a relation for alluvial cover [e.g., Sklar and Dietrich, 2004; Chatanantavet and Parker, 2008], and the gravel 
transport relation for size mixtures of Parker [1990], which accounts for the effect of differential transport. We finish this section by deriving the final equations used in model calculations.

\subsubsection{Abrasion Coefficient and Sternberg's Law}

[14] Let $D$ denote characteristic grain size, $V_{p}$ denote grain volume, and $x$ denote a downstream coordinate. The size reduction of grains in the downstream direction has long been approximated in terms of Sternberg's law; where $\alpha$ is an abrasion coefficient and $D_{o}$ is an upstream value of $D$,

$$
D=D_{o} e^{-\alpha x}
$$

or equivalently,

$$
\frac{d V_{p}}{d x}=-\beta V_{p}
$$

where $\beta=3 \alpha$. According to equation (1), the upstream grain size $D_{o}$ abrades down to size $D$ at distance $x$ from the origin, at a rate given by $\alpha\left[\mathrm{L}^{-1}\right]$. Particles are presumed to abrade by shedding silt, or in some cases sand, generated by wear. In equation (2), $\beta$ is an abrasion coefficient $\left[\mathrm{L}^{-1}\right]$ characterizing the fraction volume of a grain that is lost per unit distance traveled. In terms of logarithmic grain size $D=2^{\Psi}$, equation (2) translates to

$$
\frac{d \psi}{d x}=-\frac{1}{3 \ln (2)} \beta
$$

It should be noted here that Sternberg's law, i.e., equation (1), is introduced as a basis for defining the abrasion coefficient $\beta$. The predictions of downstream change in grain size presented here are not in any way constrained to produce the exponential variation of equation (1).

[15] Before the work of Kodama [1994b], several previous researchers had found the abrasion coefficient to be around the order of $10^{-4}-10^{-3} \mathrm{~km}^{-1}$ for chert, quartzite, granite, and limestone [e.g., Krumbein, 1941; Kuenen, 1956; Bradley, 1970]. This led to the conclusion that in many streams selective sorting may dominate abrasion in downstream fining. Kodama [1994b], however, argued that the force of impact of gravel particles in previous studies was much smaller than that in natural rivers during floods and that tumbling mills in previous studies only shed silt, with the number of clasts in the mill remaining constant in time. In contrast, in his rotating drum the force of impact was more violent. Thus, his definition of abrasion includes all mechanism of breakdown, i.e., fracturing, crushing, superficial cracking, grinding, etc. Kodama found that the abrasion coefficient in his drum was on the order of $10^{-2}-10^{-1}$ $\mathrm{km}^{-1}$ for chert, quartzite, and andesite. Comparing with field data from Watarase River, Japan, in which the calculated value of abrasion coefficient was found to have the same order of magnitude as the values from his rotating drum, he then concluded that abrasion (by his definition) should be at least in part responsible for, and in some cases should dominate, downstream fining in this river.

\subsubsection{Probability Density Function}

[16] The present study is focused on gravel or coarser particles, here lumped together as "gravel." In the steep mountain streams in question, sand and silt are treated as wash load and are not considered explicitly in the present study. When dealing with grain size distributions, the concept of probability density functions proves useful. Again, let $\psi=\ell n_{2}(D)=\ln (D) / \ell n(2)$, a logarithmic grain size (psi scale). The volume probability density that a gravel bed load particle is of size $\psi$ is given by $p(\psi)$. The volume probability density that gravel in the bed surface (active) layer is of size $\psi$ is given by $F(\psi)$. Both should satisfy the constraints

$$
\begin{aligned}
& \int_{1}^{\infty} p(\psi) d \psi=1 \\
& \int_{1}^{\infty} F(\psi) d \psi=1 .
\end{aligned}
$$

The lower limit in the integrals, i.e., $\psi=1$, corresponds to $D=$ $2 \mathrm{~mm}$, i.e., the border between gravel and sand.

[17] In addition to volume probability density, the areal probability density that sediment in the bed surface layer is of size $\psi$ must also be used in the model. This density is here denoted as $F_{a}(\psi)$. According to Parker [1991a], it should be related to $F(\psi)$ according to the relation

$$
F_{a}(\psi)=\frac{F(\psi) 2^{-(1 / 2) \psi}}{\int_{1}^{\infty} F(\psi) 2^{-(1 / 2) \psi} d \psi}
$$

Likewise, $p_{L}(\psi)$ is volume probability density of sediment in lateral input derived from adjacent hillslopes. It also satisfies the condition

$$
\int_{1}^{\infty} p_{L}(\psi) d \psi=1
$$

Note that by definition, material finer than $2 \mathrm{~mm}$ has been excluded from the hillslope material as well. This material is also assumed to travel down the river as wash load during floods as a simplifying assumption.

[18] Let $q_{b d}(\psi)$ be volume bed load transport rate per unit width $\left(\mathrm{L}^{2} \mathrm{~T}^{-1}\right)$ of grain size $\psi$. The total volume bed load transport rate per unit width summed over all grain sizes, $q_{b T}$, is then given as

$$
q_{b T}=\int_{1}^{\infty} q_{b d} d \psi
$$

\subsubsection{Abrasion Terms and Volume Transfer Rate}

[19] Abrasion produces silt as the gravel particles collide and causes the gravel particles to become smaller in size (finer) as they do so. The volume loss density per unit bed area per unit time due to abrasion of bed load particles, $A_{\text {bed }}$ load, $\left[\mathrm{L} \mathrm{T}^{-1}\right]$ is then given with the aid of an appropriate continuity condition as

$$
A_{\text {bed load }}=\beta v_{b} \xi_{b d}=\beta q_{b T} p,
$$

where $v_{b}(\psi)$ is velocity of bed load particle of size $\psi$ and $\xi_{b d}(\psi)$ is volume density per unit bed area of bed load particles in motion of size $\psi$ [Parker, 1991a]. Assuming that as a bed load particle strikes the bed, the same fraction of sediment is removed from the bed particle as the bed, the 


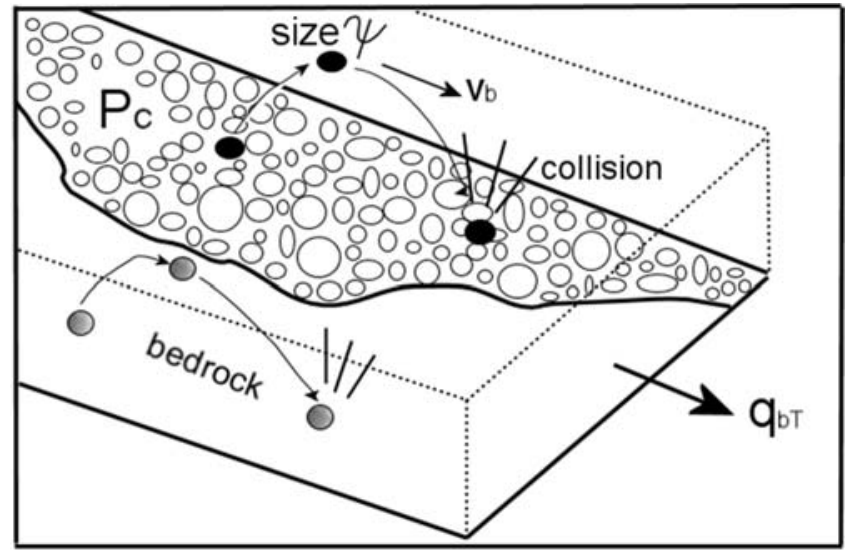

Figure 1. Schematic of collision between bed load and bed particles (black ovals) and collision between bed load particle and bedrock bed (gray circles). $P_{c}$ denotes the fraction of bedrock surface that is covered by alluvium; $v_{b}$ denotes velocity of the bed load particle; and $q_{b T}$ denotes the total volume bed load transport rate per unit width.

volume loss density per unit bed area per unit time due to abrasion of bed particles, $A_{\mathrm{bed}},\left[\mathrm{L} \mathrm{T}^{-1}\right]$ is given as

$$
A_{\text {bed }}=\beta q_{b T} P_{c} F_{a},
$$

where $P_{c}$ is fraction of bedrock surface that is covered by alluvium. In equation (9) the term $P_{c}$ accounts for the fact that not all of the bed is covered with alluvium and the term $F_{a}$ accounts for the fact that it is areal density, not volume density, that governs the exposure of bed particles to abrasion. Figure 1 illustrates the schematic of collision between bed load and bed particles as well as collision between bed load particle and bedrock bed. The total abrasion rate $A_{\text {tot }}[\mathrm{L}$ $\left.\mathrm{T}^{-1}\right]$ is then given as

$$
A_{\mathrm{tot}}=\beta q_{b T}\left(p+P_{c} F_{a}\right) .
$$

As particles abrade, they become finer; that is, they are fluxed through $\psi$ space from large $\psi$ to fine $\psi$. The velocity of flux is given as $d \psi / d t$, where from equation (3)

$$
\frac{d \psi}{d t}=\frac{d \psi}{d x} \frac{d x}{d t}=-\frac{1}{3 \ln (2)} \beta v_{b} .
$$

The volume transfer rate per unit time per unit bed area, or flux, through $\psi$ space of bed load sediment $T_{\text {bed load }}\left[\mathrm{L} \mathrm{T}^{-1}\right]$, is thus given as volume bed load sediment per unit area times "velocity" or

$$
T_{\text {bed load }}=\xi_{b d} \frac{d \psi}{d t}=-\frac{1}{3 \ln (2)} \beta \xi_{b d} v_{b}=-q_{b T} \frac{1}{3 \ln (2)} \beta p .
$$

The minus sign ensures that the transfer by abrasion is from coarser to finer sizes. If a bed load particle strikes bedrock, it abrades bedrock, which does not change the volume of gravel in the bed, because the products of abrasion are assumed to be transported as wash load. If a gravel bed load particle strikes a gravel bed particle, however, it reduces the volume of coarse-grained alluvium in the bed. The volume transfer rate per unit time per unit bed area of gravel bed particles through $\psi$ space $T_{\text {bed }},\left[\mathrm{L} \mathrm{T}^{-1}\right]$, is then given as

$$
T_{\text {bed }}=-q_{b T} \frac{1}{3 \ln (2)} \beta P_{c} F_{a} \text {. }
$$

The total density of transfer rate of gravel of size $\psi$ per unit bed area per unit time $T_{\text {tot }}$ through $\psi$ space at size $\psi$ is thus given as

$$
T_{\text {tot }}=T_{\text {bed load }}+T_{\text {bed }}=-q_{b T} \frac{1}{3 \ln (2)} \beta\left(p+P_{c} F_{a}\right) .
$$

\subsubsection{Sediment Mass Conservation}

[20] Consider a reach of river extending from $x$ to $x+\Delta x$ and a grain size range extending from $\psi$ to $\psi+\Delta \psi$. A 1-D conservation relation for bed sediment for gravel size mixtures moving as bed load can be formulated using the active layer concept [e.g., Hirano, 1971] in a way analogous to the method of Parker [1991a] but using densities instead of fractions [Parker, 1992]. The reduced form of the sediment conservation relation is found to be

$$
\begin{aligned}
B\left(1-\lambda_{p}\right)\left[\frac{\partial}{\partial t}\left(L_{a} F\right)+f_{I} \frac{\partial}{\partial t}\left(\eta-L_{a}\right)\right] \Delta x \Delta \psi \\
=\left[\left.\left(B q_{b T} p\right)\right|_{x}-\left.\left(B q_{b T} p\right)\right|_{x+\Delta x}\right] \Delta \psi+I_{L T} p_{L} \Delta x \Delta \psi \\
-B A_{t o t} \Delta x \Delta \psi+\left(\left.T_{t o t}\right|_{\psi}-\left.T_{t o t}\right|_{\psi+\Delta \psi}\right) B \Delta x
\end{aligned}
$$

where $B$ is channel width, which can vary with downstream distance; $\lambda_{p}$ is bed porosity; $L_{a}$ is thickness of the active layer (effective thickness of alluvium averaged over bedrock surface), $f_{l}(\psi)$ is volume probability density of size $\psi$ of sediment exchanged at the interface between the surface and any substrate as the bed aggrades or degrades; $t$ is time; $\eta$ is mean bed elevation; and $I_{L T}$ is volume input of gravel of all sizes per unit distance downstream per unit time input from hillslopes. The above form can further be reduced to

$$
\begin{aligned}
B(1- & \left.\lambda_{p}\right)\left[\frac{\partial}{\partial t}\left(L_{a} F\right)+f_{I} \frac{\partial}{\partial t}\left(\eta-L_{a}\right)\right] \\
& =-\frac{\partial B q_{b T} p}{\partial x}+I_{L T} p_{L}-B A_{t o t}-B \frac{\partial T_{t o t}}{\partial \psi}
\end{aligned}
$$

Substituting equations (10) and (14) into equation (16), one finds

$$
\begin{aligned}
B\left(1-\lambda_{p}\right) & {\left[\frac{\partial}{\partial t}\left(L_{a} F\right)+f_{I} \frac{\partial}{\partial t}\left(\eta-L_{a}\right)\right] } \\
= & -\frac{\partial B q_{b T} p}{\partial x}+I_{L T} p_{L}-B \beta q_{b T}\left(p+P_{c} F_{a}\right) \\
& +\frac{B \beta q_{b T}}{3 \ln (2)} \frac{\partial}{\partial \psi}\left(p+P_{c} F_{a}\right) .
\end{aligned}
$$

Integrating the above equation from $\psi=1$ to $\psi=\infty$ and invoking equations (4a), (4b), (5), and (6), equation (17) reduces to

$$
\begin{aligned}
B\left(1-\lambda_{p}\right) \frac{\partial \eta}{\partial t}= & -\frac{\partial B q_{b T}}{\partial x}+I_{L t}-B \beta q_{b T}\left(1+P_{c}\right) \\
& -\frac{B \beta q_{b T}}{3 \ln (2)}\left(\left.p\right|_{\psi=1}+\left.P_{c} F_{a}\right|_{\psi=1}\right) .
\end{aligned}
$$


The second-to-last term on the right-hand side of equation (18) quantifies the rate of loss of gravel volume to silt by grinding, and the last term quantifies the rate of loss to sand (as gravel particles are ground so fine that they cross the gravel-sand threshold of $2 \mathrm{~mm}$ ).

[21] A flood intermittency $I$ (fraction of time the river is in the considering flood) is used to characterize the fact that the river is morphodynamically active only for a small fraction of real time. Equations (17) and (18) become, respectively,

$$
\begin{aligned}
B\left(1-\lambda_{p}\right) & {\left[\frac{\partial}{\partial t}\left(L_{a} F\right)+f_{I} \frac{\partial}{\partial t}\left(\eta-L_{a}\right)\right] } \\
= & -I \frac{\partial B q_{b T} p}{\partial x}+I_{L T} p_{L}-I B \beta q_{b T}\left(p+P_{c} F_{a}\right) \\
& +I \frac{B \beta q_{b T}}{3 \ln (2)} \frac{\partial}{\partial \psi}\left(p+P_{c} F_{a}\right)
\end{aligned}
$$

$$
\begin{aligned}
B\left(1-\lambda_{p}\right) \frac{\partial \eta}{\partial t}= & -I \frac{\partial B q_{b T}}{\partial x}+I_{L T}-I B \beta q_{b T}\left(1+P_{c}\right) \\
& -I \frac{B \beta q_{b T}}{3 \ln (2)}\left(\left.p\right|_{\psi=1}+\left.P_{c} F_{a}\right|_{\psi=1}\right) .
\end{aligned}
$$

Assume that bedrock incision occurs so slowly that the pattern of downstream fining can be taken as quasi-steady state. Alternatively, assume that a steady state condition takes place. Thus, equations (19) and (20) become, respectively,

$$
\begin{gathered}
\frac{d B q_{b T} p}{d x}=\frac{I_{L T} p_{L}}{I}-B \beta q_{b T}\left(p+P_{c} F_{a}\right)+\frac{B \beta q_{b T}}{3 \ln (2)} \frac{\partial}{\partial \psi}\left(p+P_{c} F_{a}\right) \\
\frac{d B q_{b T}}{d x}=\frac{I_{L T}}{I}-B \beta q_{b T}\left(1+P_{c}\right)-\frac{B \beta q_{b T}}{3 \ln (2)}\left(\left.p\right|_{\psi=1}+\left.P_{c} F_{a}\right|_{\psi=1}\right) .
\end{gathered}
$$

From equations (21) and (22), we obtain the following final forms of the governing equations for downstream fining in bedrock rivers with lateral (hillslope) input:

$$
\begin{aligned}
B q_{b T} \frac{d p}{d x}= & \frac{I_{L T}\left(p_{L}-p\right)}{I}-B \beta q_{b T} P_{c}\left(F_{a}-p\right) \\
& +\frac{B \beta q_{b T}}{3 \ln (2)}\left[\frac{\partial}{\partial \psi}\left(p+P_{c} F_{a}\right)+p\left(\left.p\right|_{\psi=1}+\left.P_{c} F_{a}\right|_{\psi=1}\right)\right]
\end{aligned}
$$

$$
\begin{aligned}
\frac{d q_{b T}}{d x}= & -\frac{q_{b T}}{B} \frac{d B}{d x}+\frac{I_{L T}}{I B}-\beta q_{b T}\left(1+P_{c}\right) \\
& -\frac{\beta q_{b T}}{3 \ln (2)}\left(\left.p\right|_{\psi=1}+\left.P_{c} F_{a}\right|_{\psi=1}\right) .
\end{aligned}
$$

Note that although the final governing equations (23a) and (23b) are written as event based, characterized by the use of the flood intermittency concept, the model development below is based on a long-term average concept since it is assumed to be in steady state condition (by omitting the bed evolution terms), and this thus reflects on the model results.
Discretized forms of equations (23a) and (23b) for use in numerical computations can be obtained as follows. The grain size distributions are discretized into $N$ grain size ranges bounded by $N+1$ sizes $D_{b, 1} . . D_{b, N+1}$ from finest to coarsest. The characteristic size of the $i$ th grain size range is $D_{i}$, where $D_{i}=\sqrt{D_{b, i} D_{b, i+1}}$ or on the logarithmic psi scale $\psi_{i}=\left(\psi_{b, i}+\right.$ $\left.\psi_{b, i+1}\right) / 2$. The subscript $k$ denotes discretized down-channel distance along the river. Thus,

$$
\begin{aligned}
p_{i, k+1}= & p_{i, k}+\frac{I_{L T, k}}{I B_{k} q_{b T, k}}\left(p_{L i, k}-p_{i, k}\right) \Delta x-\beta P_{c, k}\left(F_{a i, k}-p_{i, k}\right) \Delta x \\
+ & \frac{\beta}{3 \ln (2)}\left[\frac{p_{i+1, k}+P_{c, k} F_{a, i+1, k}}{\Delta \psi_{i+1}}-\frac{p_{i, k}+P_{c, k} F_{a i, k}}{\Delta \psi_{i}}\right. \\
+ & \left.\frac{p_{i, k}}{\Delta \psi_{1}}\left(p_{1, k}+P_{c, k} F_{a 1, k}\right)\right] \Delta x \\
q_{b T, k+1}= & q_{b T, k}-\frac{q_{b T, k}}{B_{k}}\left(B_{k+1}-B_{k}\right) \\
& +\left[\frac{I_{L T, k}}{I B_{k}}-\beta q_{b T, k}\left(1+P_{c, k}\right)\right. \\
& \left.-\frac{\beta q_{b T, k}}{3 \ln (2)} \frac{\left(p_{1, k}+P_{c, k} F_{a 1, k}\right)}{\Delta \psi_{1}}\right] \Delta x .
\end{aligned}
$$

\subsubsection{Other Pertinent Relations Used in the Model}

[22] The downstream variation of channel width $B$ can be computed from empirical relations that can be calibrated to be site-specific. For example, let $x$ denote a down-channel distance (with an appropriately defined origin near the headwaters of the basin) and $A(x)$ denote the drainage area upstream of point $x$. It is commonly assumed that $B$ depends on $A$ [e.g., Montgomery and Gran, 2001] as

$$
\begin{aligned}
& B=\alpha_{b} A^{n_{b}} \\
& A=K_{h} x^{n_{h}} .
\end{aligned}
$$

Equation (25b) is known as Hack's law [Hack, 1957]. Reasonable values for $\alpha_{b}, n_{b}, K_{h}$, and $n_{h}$ are $0.02,0.4,6.7$, and 1.7, respectively [e.g., Montgomery and Gran, 2001; Hack, 1957].

[23] A gross estimate of volume input of sediment per unit distance downstream per unit time from hillslopes $I_{L T}$ is readily written as [e.g., Chatanantavet, 2007; Chatanantavet and Parker, 2009]

$$
I_{L T}=v_{d} \frac{d A}{d x}
$$

where $v_{d}$ is an estimate of the denudation rate (speed of erosion of the surface) of the hillslope area $\Delta A$ adjacent to the stream between $x$ and $x+\Delta x$. Figure 2 illustrates the schematic of this process.

[24] The simplest possible form for the fraction of bedrock surface that is covered by alluvium has been found to be

$$
P_{c}=\left\{\begin{array}{cc}
\frac{q_{b T}}{q_{b T c}} \quad, \quad q_{b T}<q_{b T c} \\
1, \quad q_{b T}=q_{b T c}
\end{array}\right.
$$




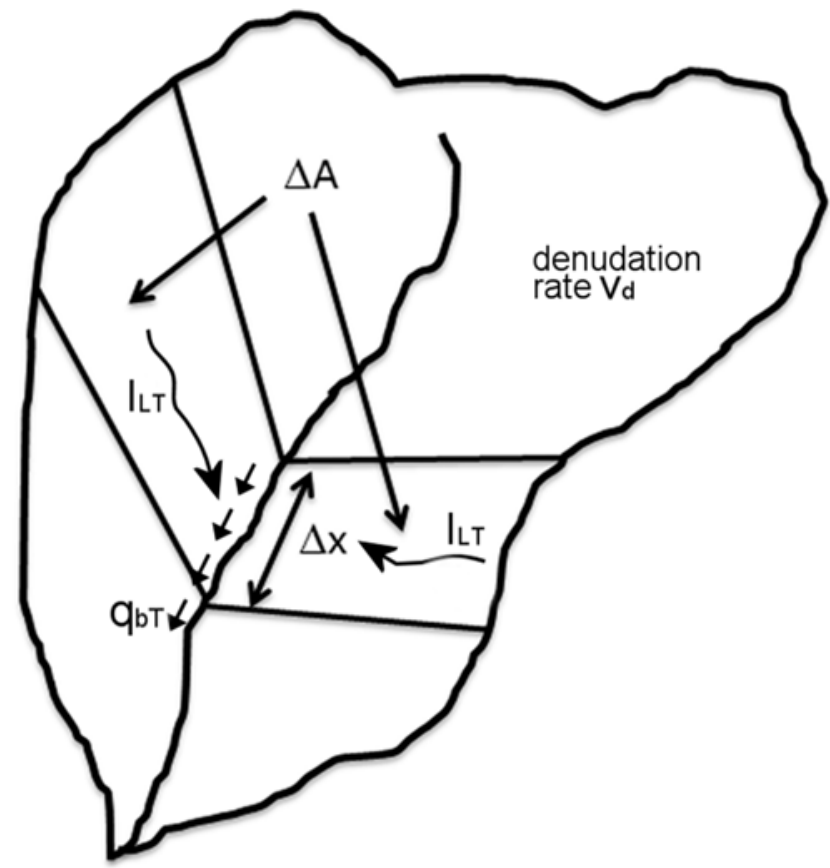

Figure 2. Illustration of a drainage basin showing the source of the sediment delivered from hillslopes. $\Delta x$ denotes a segment of down-channel distance; $\Delta A$ denotes a segment of the drainage area for the distance $\Delta x ; I_{L T}$ denotes the volume input of sediment of all sizes per stream length per unit time entering the channel from the hillslopes; and $q_{b T}$ denotes the total volume bed load transport rate per unit width. Figure modified from Chatanantavet and Parker [2009].

where $q_{b T c}$ denotes the capacity transport rate of gravel [e.g., Sklar and Dietrich, 2004; Chatanantavet and Parker, 2008]. By definition, if bedrock is exposed, then the supply of gravel is below capacity; otherwise, the bedrock would be covered by alluvium.

[25] Here the capacity transport rate $q_{b T c}$ is computed using the gravel transport relation of Parker [1990]. Although another relation such as that of Wilcock and Crowe [2003] could also be used, the Parker [1990] relation is convenient because it tracks only gravel transport and sand is assumed to be transported as wash load, as stated earlier. A full description of the relation can be found in the work by Parker [1990]. Here, the relation can be written in shorthand form as

$$
q_{b T c} p_{i}=\alpha_{p} u_{*}^{3} F_{i} G_{i}\left(\bar{\psi}_{s}, \sigma_{s}, u *\right)
$$

where $\alpha_{p}$ is a constant (equal to $0.00218 /(R g)$ ), $R$ denotes the submerged specific gravity of gravel $(\sim 1.65$ for most natural sediments), $g=9.81 \mathrm{~m} \mathrm{~s}^{-2}$ denotes gravitational acceleration, $u_{*}$ denotes shear velocity, and $G_{i}$ is a complicated grain size-specific function specified by Parker [1990] that ultimately involves only shear velocity $u *$, the surface arithmetic mean size on the psi scale $\bar{\psi}_{s}$, and the surface arithmetic standard deviation $\sigma_{s}$ on the psi scale. The surface geometric mean size $D_{s g}$ and surface geometric standard deviation $\sigma_{s g}$ are given as

$$
D_{s g}=2^{\bar{\psi}_{s}}
$$

$$
\sigma_{s g}=2^{\sigma_{s}}
$$

where

$$
\begin{array}{r}
\bar{\psi}_{s}=\sum_{i=1^{\prime}}^{N} \psi_{i} F_{i} \\
\sigma_{s}^{2}=\sum_{i=1^{\prime}}^{N}\left(\psi_{i}-\bar{\psi}_{s}\right)^{2} F_{i} .
\end{array}
$$

The shear velocity $u *$ can be estimated from the relations [e. g., Parker, 1991a; Parker, 2004], assuming a normal distribution for $\bar{\psi}_{s}$ and $\sigma_{s}$ :

$$
\begin{gathered}
u *=2^{\left[\left(\bar{\psi}_{s}+1.27 \sigma_{s}\right) / 20\right]} \hat{u} \\
\hat{u}=\alpha_{r}^{-3 / 10} n_{k}^{1 / 20}\left(\frac{i A}{B}\right)^{3 / 10} g^{7 / 20} S^{7 / 20},
\end{gathered}
$$

where $\alpha_{r}$ is a coefficient in the Manning-Strickler resistance relation that can be set equal to 8.1 [Parker, 1991b], $n_{k}$ is a constant characterizing roughness height $\sim 1.5$ to $3, i$ is effective rainfall rate (during floods of appropriate magnitude), and $S$ is channel slope. It is assumed here that appropriate forms or values for $A, B, S$, and $i$ are specified. Then equations (31a) and (31b) can be used to reduce equation (28) to a simpler functional form in which the only unknowns are $\bar{\psi}_{s}$ and $\sigma_{s}$ :

$$
q_{b T c} p_{i}=\alpha_{p} \Omega\left(\bar{\psi}_{s}, \sigma_{s}\right) \hat{u}^{3} F_{i} \tilde{G}_{i}\left(\bar{\psi}_{s}, \sigma_{s}, \hat{u}\right),
$$

where

$$
\begin{array}{rlc}
\Omega\left(\bar{\psi}_{s}, \sigma_{s}\right) & \equiv & 2^{\left[3\left(\bar{\psi}_{s}+1.27 \sigma_{s}\right) / 20\right]} \\
\tilde{G}_{i}\left(\bar{\psi}_{s}, \sigma_{s}, \hat{u}\right) & \equiv G_{i}\left(\bar{\psi}_{s}, \sigma_{s}, 2^{\left[\left(\bar{\psi}_{s}+1.27 \sigma_{s}\right) / 20\right]} \hat{u}\right) .
\end{array}
$$

\subsubsection{Completion: Solution for Surface and Bed Load Size Fractions}

[26] The goal of this model is to compute the downstream variation of $\bar{\psi}_{s}$ and $\sigma_{s}$. In order to calculate these values, associated equations are developed as follows. The capacity transport rate of the channel $q_{b T c}$ can be computed by solving equation (32) for $F_{i}$ and summing so that

$$
q_{b T c}=\frac{\alpha_{p} \Omega\left(\bar{\psi}_{s}, \sigma_{s}\right) \hat{u}^{3}}{\sum_{i=1}^{N} \frac{p_{i}}{\tilde{G}_{i}\left(\bar{\psi}_{s}, \sigma_{s}, \hat{u}\right)}} .
$$

$F_{i}$ is then computed from equations (32) and (33) as

$$
F_{i}=\frac{\frac{p_{i}}{\tilde{G}_{i}\left(\bar{\psi}_{s}, \sigma_{s}, \hat{u}\right)}}{\sum_{i=1}^{N} \frac{p_{i}}{\tilde{G}_{i}\left(\bar{\psi}_{s}, \sigma_{s}, \hat{u}\right)}} .
$$


$F_{a i}$ is then computed from $F_{i}$ and the discretized form of equation (5), which is

$$
F_{a i}=\frac{F_{i} 2^{-(1 / 2) \psi_{i}}}{\sum_{i=1}^{N} F_{i} 2^{-(1 / 2) \psi_{i}}} .
$$

The basis for computing $\bar{\psi}_{s}$ and $\sigma_{s}$ is equation (35), and the definitions are from equations (30a) and (30b). Applying $F_{i}$ in equation (35) into equations (30a) and (30b) and introducing new parameters, one finds

$$
\begin{gathered}
\Phi_{1}\left(\bar{\psi}_{s}, \sigma_{s}\right)=0 \\
\Phi_{2}\left(\bar{\psi}_{s}, \sigma_{s}\right)=0,
\end{gathered}
$$

where

$$
\begin{array}{r}
\Phi_{1}=\bar{\psi}_{s}-\frac{\sum_{i=1}^{N} \frac{\psi_{i} p_{i}}{\tilde{G}_{i}\left(\bar{\psi}_{s}, \sigma_{s}, \hat{u}\right)}}{\sum_{i=1}^{N} \frac{p_{i}}{\tilde{G}_{i}\left(\bar{\psi}_{s}, \sigma_{s}, \hat{u}\right)}} \\
\Phi_{2}=\sigma_{s}^{2}-\frac{\sum_{i=1}^{N} \frac{\left(\psi_{i}-\bar{\psi}_{s}\right)^{2} p_{i}}{\tilde{G}_{i}\left(\bar{\psi}_{s}, \sigma_{s}, \hat{u}\right)}}{\sum_{i=1}^{N} \frac{p_{i}}{\tilde{G}_{i}\left(\bar{\psi}_{s}, \sigma_{s}, \hat{u}\right)}} .
\end{array}
$$

The above equations can be solved iteratively using a Newton-Raphson technique. The formulation leads to a matrix equation which can be solved using, e.g., Doolittle's method, which is employed here.

\subsubsection{Flow of the Calculation}

[27] The model calculation flows as follows.

[28] 1. The input variables $S, B, i, p_{L i}, I_{L T}$, and $\hat{u}$ need to be specified in advance, either as prescribed constants or as known functions of $x$.

[29] 2. Upstream values of $q_{b T}$ and $p_{i}$ are imposed as boundary conditions.

[30] 3. From the given upstream values of $p_{i}$ and $\hat{u}, F_{i}$ and $q_{b T c}$ are computed from equations (35) and (34), and then $P_{c}$ and $F_{a i}$ are computed from equations (27) and (36).

[31] 4. Having done this, equations (24a) and (24b) can be used to find $p_{i}$ and $q_{b T}$ one step downstream.

[32] 5. Once $p_{i}$ is known one step downstream, a repeat of step 3 determines $F_{i}, q_{b T c}, P_{c}$, and $F_{a i}$ at that node.

[33] 6. Repeat the above steps downstream.

\subsection{Exponential Form of Channel Slope}

[34] In principle, the above model could be coupled with a model of channel incision to describe the evolution of the long profile of the stream in addition to downstream fining. For the present modeling purposes, however, it is convenient to specify channel slope in the formulation. Here a concave-upward bed profile is used such that the channel slope $S$ decreases exponentially from upstream to downstream as shown in equations (39) and (40):

$$
S=S_{u} e^{-c\left(x-x_{u}\right)}
$$

$$
c=\frac{\ln \left(S_{u} / S_{d}\right)}{L}
$$

where $S_{u}$ is bed slope at the upstream boundary of the study reach, $x_{u}$ is distance from the upstream divide to the upstream boundary of the study reach, $S_{d}$ is bed slope at the downstream boundary of the study reach, and $L$ is the total down-channel length of the study reach.

\section{Model Testing Against Field Data}

[35] In this section, the model developed in section 2 is run with input parameters from field data, and the results are shown. We have used Microsoft ${ }^{\circledR}$ Excel and Visual Basic and Applications code to build the outlined numerical model. The numerical model outputs consist of plots of the downstream variations of surface geometric mean grain size $D_{s g}$ and surface $D_{90}$ (such that $90 \%$ by volume of grains are finer), bed load transport rate, bed load transport capacity, areal fraction of alluvial coverage during floods and low flow, and grain size distributions of bed load material and surface material at various points along the stream. The model results and sensitivity analysis are then evaluated and discussed.

\subsection{Field Description: Guadeloupe Island}

[36] Basse-Terre Island belongs to the archipelago of Guadeloupe and is in fact a part of Guadeloupe Island. Guadeloupe Island consists of Basse-Terre Island and Grand-Terrre Island, which are connected by a narrow isthmus. It is located in the volcanic arc of the Lesser Antilles, which was created by subduction of the Atlantic Ocean lithosphere beneath the Caribbean plate. Basse Terre Island consists of seven main eruptive fields [Komorowski et al., 2005]. Age determination by Blanc [1983], Carlut et al. [2000], Carlut and Quidelleur [2000], and Samper et al. [2007] have constrained the timing of volcanism. BasseTerre Island is characterized by a quite uniform andesitic lithology: the terrain is composed of lava flows and eroded volcanic edifices dated between 2.79 Myr in the north of Basse-Terre (Basal Complex and Septentrional Chain) to 0 Myr for the present-day active Grande Découverte-La Soufrière volcanic complex in the south. Volcanic massifs ages are correlated with their maximum elevations. The youngest massif (Grande Découverte) culminates at $1437 \mathrm{~m}$. Toward the north, maximum elevations decrease progressively to $1000 \mathrm{~m}$ for the axial chain, $700 \mathrm{~m}$ for the Septentrional Chain and $400 \mathrm{~m}$ for the Basal Complex. A recent investigation of tectonics [Feuillet et al., 2001, 2004] has revealed that Basse-Terre Island is affected by east-west conjugated normal faults which delineate a complex $20 \mathrm{~km}$ wide graben. The southern fault marks the limit between the Caraïbes massif and the Grande Découverte massif. The northern fault crosscuts the axial chain from Bouillante to Sainte Marie.

[37] The climate of Basse-Terre is tropical, with high temperatures $\left(24^{\circ} \mathrm{C}-28^{\circ} \mathrm{C}\right)$ and high precipitation rates. Averaged annual runoff ranges from $2700 \mathrm{~mm} \mathrm{yr}^{-1}$ on the west (leeward) coast to $3100 \mathrm{~mm} \mathrm{yr}^{-1}$ on the east (windward) coast. The hydrologic regime is torrential: tropical storms and hurricanes are frequent, particularly during the 


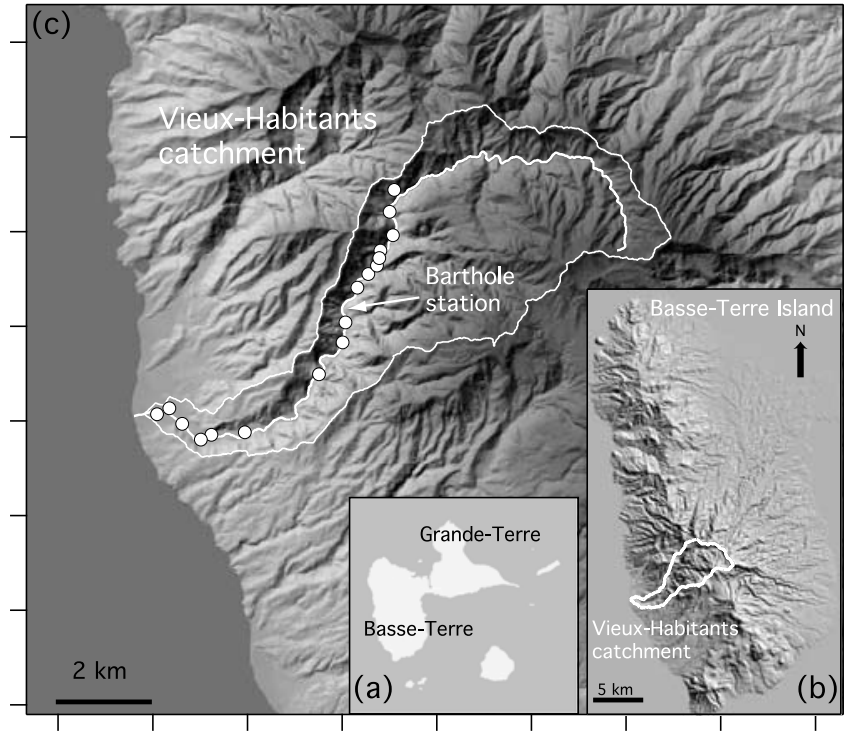

Figure 3. (a) Map of the Guadeloupe archipelago showing both Basse-Terre and Grande-Terre islands. (b) Topographic map of Basse-Terre Island. Vieux Habitants catchment is located in the southwest of Basse-Terre Island. (c) Close-up topographic map of Vieux Habitants catchment. The catchment divide and the river channel are drawn in white. Circles indicate the position of the sites where granulometric measurements were performed. Barthole station indicates the approximate location where a bedrock-alluvial reach in the upstream part of this river apparently transitions to an alluvial reach toward the ocean. Latitudes of the field site are $16^{\circ} 00^{\prime} 00^{\prime \prime}$ and $16^{\circ} 10^{\prime} 00^{\prime \prime}$, and longitudes are $61^{\circ} 40^{\prime} 00^{\prime \prime}$ and $61^{\circ} 50^{\prime} 00^{\prime \prime}$.

rainy season, which spans the period from June to January. Vegetation is dense and tropical, and soils are very thick. The landscape is controlled by the competition between effusive volcanism and tectonic uplift on the one hand and weathering and erosion processes on the other. These are qualitatively similar to those at work in many active mountain belts. Rivers and debris flows cut the bedrock, while landslides limit the relief of interfluves. Topography is characterized by a high-relief ridge-and-valley landscape, with straight, steep hillslopes and a well-connected channel network, which evacuates erosion products over the long term. Episodic intense rainfalls trigger landslides and flash floods and cause significant transport of dissolved and solid materials in rivers in the form of alluvial river flows, as well as mud or debris flows. The impact of these events on the long-term denudation rate is yet unquantified.

[38] We conducted a data collection campaign on the Vieux Habitants River in February of 2007. This river, located in the southwest of Basse-Terre Island and draining into the leeward coast, has a length of $\sim 19 \mathrm{~km}$ (Figure 3). Its bed elevation varies from $1100 \mathrm{~m}$ at its most upstream end to $0 \mathrm{~m}$ at the Vieux Habitants village, where it reaches the sea. The total drainage area is approximately $30 \mathrm{~km}^{2}$. It is characterized by a concave-upward profile of bed elevation and high channel slopes of approximately $8 \%$ upstream to $2 \%$ downstream (Figure 4a). Most of the river catchment is located within a national park, so anthropogenic forcing is expected to be weak. Vegetation is very dense, and the lithology is relatively uniformly andesitic. The lateral hillslope angles in the upstream and downstream areas are also shown in Figure 4a. The upstream ones were observed to be steeper than the downstream counterparts.

[39] The denudation rate of the Vieux Habitants catchment has been estimated to be about $610 \mathrm{~mm} \mathrm{kyr}^{-1}$, by means of a geochemical mass balance method [Rad et al., 2006]. This erosion rate has recently been confirmed by Lajeunesse et al. [2009], in which a digital elevation model (DEM) was used to estimate the total volume removed by erosion. On the basis of the measurements of Samper et al. [2007], they deduced the basin averaged denudation rate to be near $400 \mathrm{~mm} \mathrm{kyr}^{-1}$. The DEM horizontal resolution is 10 $\mathrm{m}$, and the vertical one is $1 \mathrm{~m}$. The source of the DEM is the Institut Geographique National in France. The river profile was extracted from the DEM using the Rivertools software.
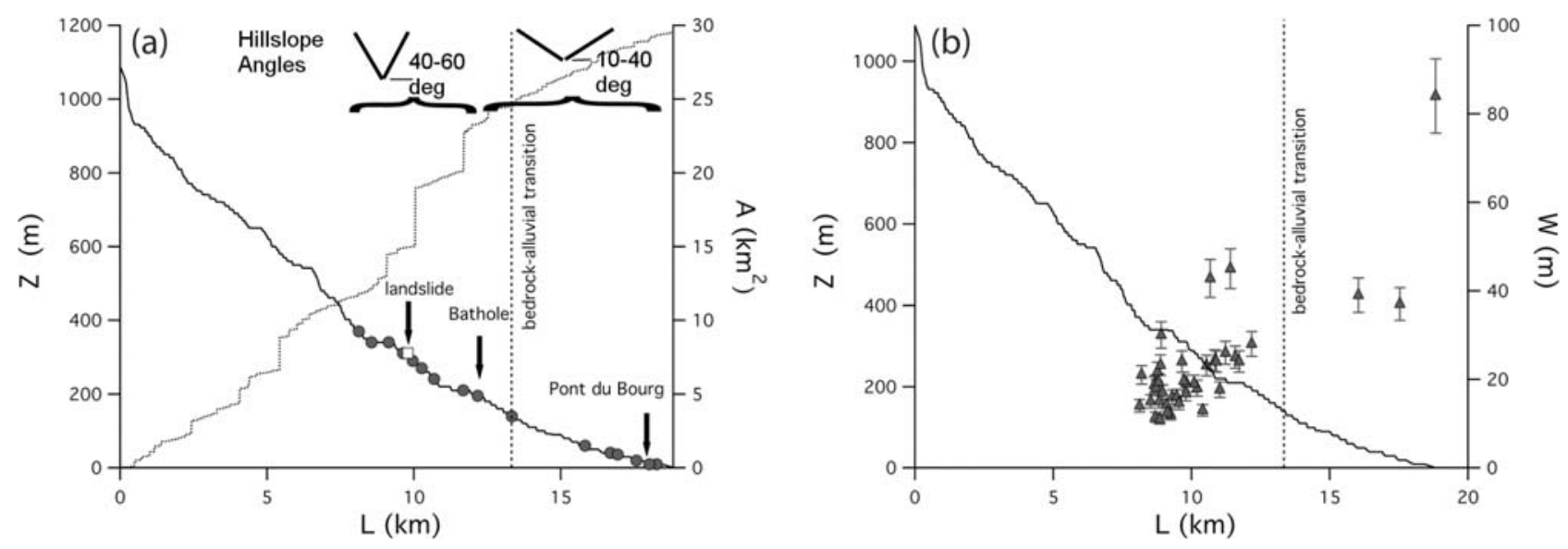

Figure 4. (a) Elevation $\eta$ (left axis and solid line) and drainage area $A$ (right axis and dotted line) of Vieux Habitants River as a function of downstream distance $x(x=0$ at the drainage divide). Circles indicate the position of the granulometric sampling sites. The lateral hillslope angles in the upstream and downstream areas are also shown. (b) Elevation $\eta$ (left axis and solid line) and river width $B$ (right axis and triangles) as a function of downstream distance $x$. The position of the bedrock-alluvial transition is indicated by a vertical dotted line in each graph. 


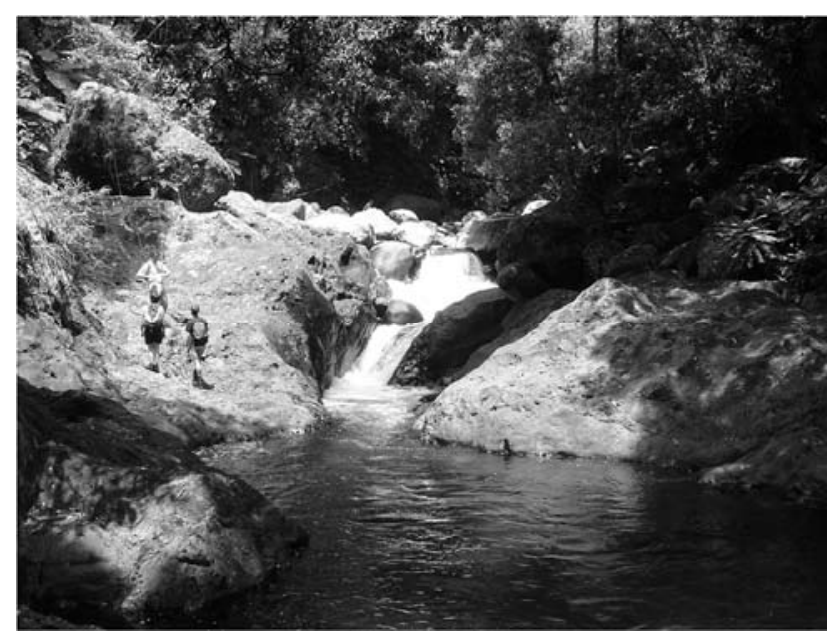

(a)

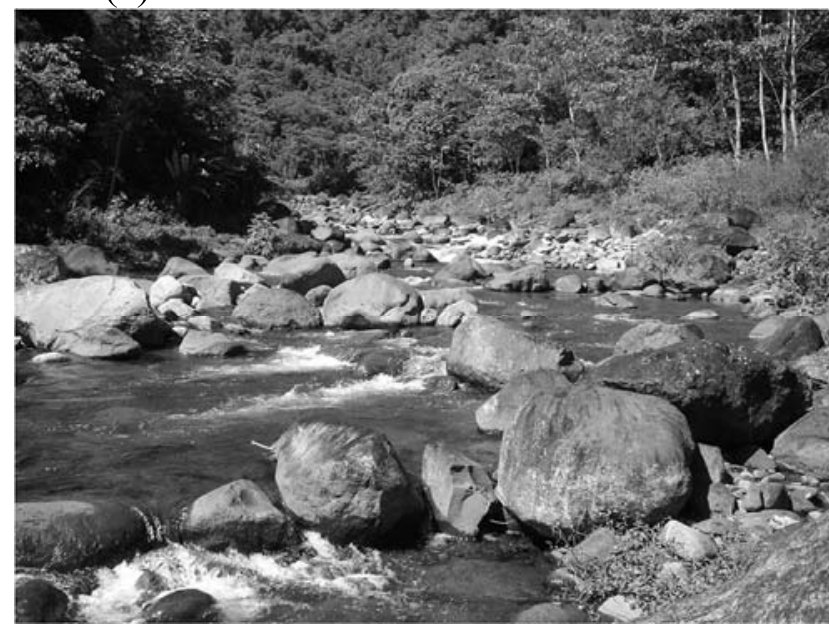

(b)

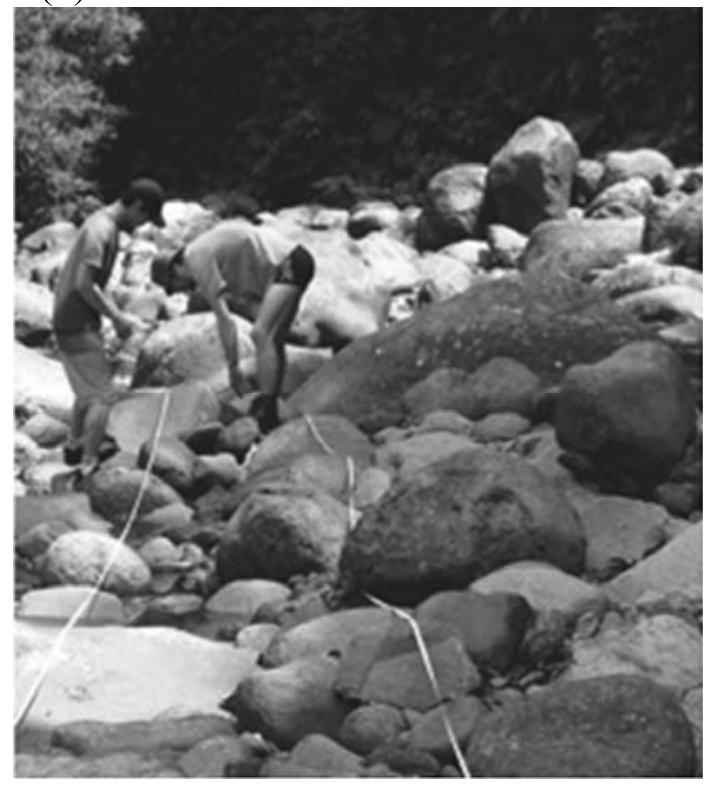

(c)

Figure 5. (a) Typical bedrock reach in the upstream part of the Vieux Habitants River (e.g., upstream of the Barthole gauging station). Note a small alluvial patch in the top part. (b) Typical alluvial reach in the downstream part of the Vieux Habitants River where bedrock exposure is no longer observed. (c) Granulometric sampling of a river bed.
[40] Upstream of the Barthole gauging station, which is $\sim 7 \mathrm{~km}$ upstream of the river mouth (Figures 3 and $4 \mathrm{a}$ ), Vieux Habitants River flows on an andesitic bedrock channel and incises a rather narrow $\mathrm{V}$-shaped valley. The dominant bedrock incision process in this river is observed to be abrasion. Its bed is partially mantled by a thin alluvial cover whose thickness can increase locally, most likely when overwhelmed by an episodic sediment supply from adjacent hillslopes, gullies, or tributaries. Not far downstream of the Barthole station, the bed of the Vieux Habitants changes from bedrock to alluvial (Figures 3 and $4 \mathrm{a}$ ), and the valley widens.

[41] Several field trips along the river allowed us to directly measure the river width up to a distance of $11 \mathrm{~km}$ from the sea by means of a laser distance meter. We were not able to walk farther upstream because the rain forest becomes very dense. In the bedrock part, the width of the river is on the order of 15 to $20 \mathrm{~m}$ (Figure $4 \mathrm{~b}$ ). Downstream of the bedrock-alluvial transition, width increases from $30 \mathrm{~m}$ near the Barthole station to $40 \mathrm{~m}$ at the sea.

[42] The water discharge of the Vieux Habitants River is monitored by the Direction Regionale de l'Environnement (DIREN). The Barthole gauging station has been recording water flow depth every $15 \mathrm{~min}$ by means of a pressure sensor since 1980. Hourly discharge data extending from 1951 to 1988 are also available from another gauging station, Pont du Bourg, which is at a distance from the sea of $1.3 \mathrm{~km}$. This station is no longer in use. Despite some gaps, this set of data covers a period long enough to characterize the hydrologic regime of the river. The discharge of the Vieux Habitants River is highly variable. Instantaneous flow rates recorded at the Barthole station between 1980 and 1993 vary between 0.4 and $250 \mathrm{~m}^{3} \mathrm{~s}^{-1}$. At the Pont du Bourg station, located farther downstream, water flow rates as high as $410 \mathrm{~m}^{3} \mathrm{~s}^{-1}$ have been recorded. These peaks of water flow rates correspond to flash floods caused by tropical storms and hurricanes. These are rather frequent during the rainy season, which spans from June to January. They are responsible for most of the bed load transport in the river.

[43] A typical bedrock reach in the upstream part of the Vieux Habitants River (e.g., upstream of the Barthole gauging station) and a typical alluvial reach in the downstream part where bedrock exposure is no longer observed are shown in Figures $5 \mathrm{a}$ and $5 \mathrm{~b}$, respectively. We used the Wolman [1954] method with a sampling interval of $1 \mathrm{~m}$ to determine the grain size distribution for 16 sites along the river (see Figures 3 and 4a). For each site, about 200 samples were recorded along the emerged part of the river bed at low flow (Figure 5c) on the basis of the assumption that these characterize the alluvial material of the bed. We used a few $100 \mathrm{~m}$ long measuring tapes stretching along the river bed as a straight line and measured the grain size at every 1 $\mathrm{m}$ interval following the methods described by Kellerhals and Bray [1971]. The median diameter decreases from about $200 \mathrm{~mm}$ at $10.3 \mathrm{~km}$ from the sea to $48 \mathrm{~mm}$ at the sea. The channel bed is characterized by the presence of numerous boulder blocks of meter size (Figure 5b) as indicated by the $D_{90}$ which varies from $1660 \mathrm{~mm}$ at $10.3 \mathrm{~km}$ from the sea to $160 \mathrm{~mm}$ at the sea. The Wolman method was also applied to characterize the granulometric distribution of a landslide deposit along the river bank (Figure 6a). The re- 


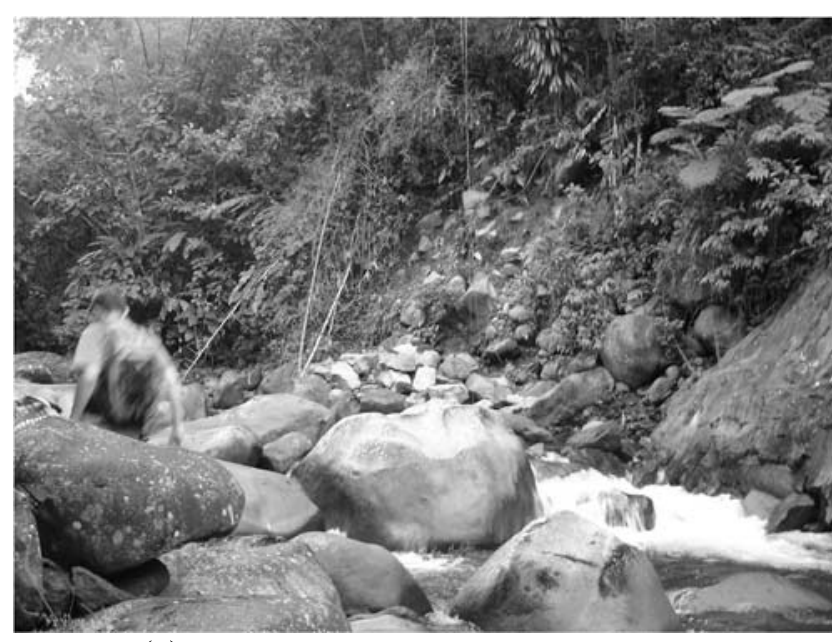

(a)

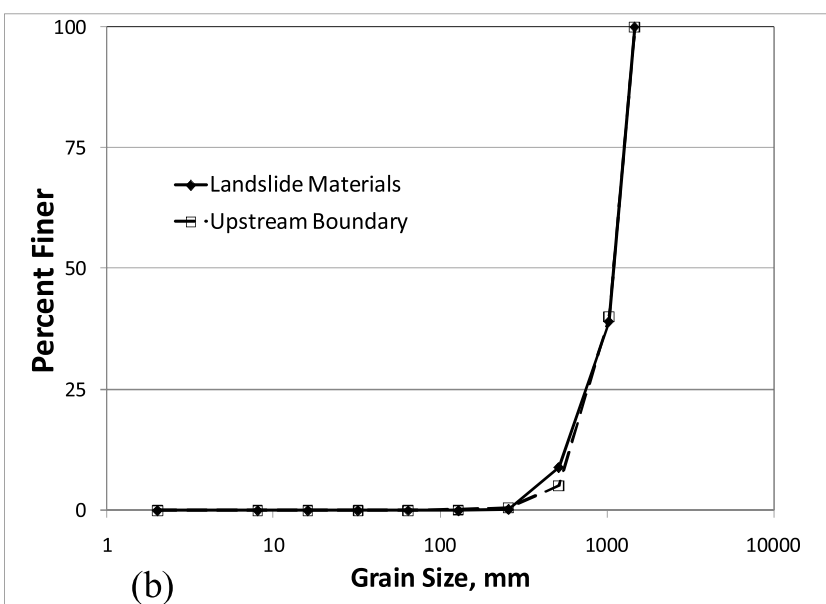

Figure 6. (a) Fresh blocky material from a landslide on the hillslope of the Vieux Habitants River. (b) Grain size distributions of the gravel part of landslide materials and of the gravel part of the bed material at the upstream boundary of the study reach, collected from the field.

sulting distribution, shown in Figure 6b, gives an idea of the size of the sediments feeding the river.

\subsection{Model Application and Results}

[44] In this section, the numerical model developed is applied to the field data from the Vieux Habitants River in Guadeloupe Island. Several power relations are used as follows in order to simulate the field data and input into the numerical model. Figure 7 a shows the field data for drainage area $A$ as a function of downstream distance $x$ in the Vieux Habitants River as deduced from the previously described DEM, as well as a power law fit corresponding to the form of Hack's [1957] law. For the most part in the upstream reach, the coefficient is the same as the value given by Hack [1957], but the exponent has been adjusted downward from 1.7 to 1.6 using the length unit of meters. In the $6 \mathrm{~km}$ portion of the reach farthest downstream, however, the drainage area increases toward downstream relatively slower because of the drainage shape (Figure 3) and can be fitted by another adapted power law as shown in Figure 7a. Figure $7 \mathrm{~b}$ shows the collected field data for channel width $B$ versus $A$, as well as a power law approximation relating the two. The coefficient and exponent, which take the values of 0.03 and 0.4 using the length unit of meters, were adapted from the form of the width-area relation for mountain streams given by Montgomery and Gran [2001]. Our field observations indicate that the channel cross section is mostly rectangular all along the river except some very steep parts where the step-pool morphology could be more pronounced. However, local width variation within the step-pools or channel nonuniformity [e.g., Wyrick and Pasternack, 2008] may not be significant enough to affect the downstream fining processes, especially for these big boulders. Finally, Figure 7c shows the field data for bed slope $S$ versus distance $x$ for the river, along with an exponential fit (equations (39) and (40)). The values of $L, S_{u}, S_{d}$, and $x_{u}$ are used as inputs to the model.

[45] Table 1 summarizes the input parameters used in this section to simulate downstream change in grain size in the Vieux Habitants River. The effective rainfall rate and flood intermittency are deduced from the flow discharge record by DIREN by statistically analyzing the typical highest flood discharges and durations and converting the result to be the effective rainfall rate, assuming a spatially uniform rainfall distribution. The basin-wide denudation rate $v_{d}$ of the Vieux Habitants drainage has been estimated to be about $0.4 \mathrm{~mm}$ $\mathrm{yr}^{-1}$ using a DEM to estimate the total volume removed by erosion [Lajeunesse et al., 2009]. The abrasion coefficient $(\beta)$ or volume fraction of grain lost per unit distance traveled is estimated for andesitic rock, which is the most common lithology in the river, on the basis of information by Kodama [1994b], Sklar and Dietrich [2001, 2004], and Chatanantavet and Parker [2009].

[46] The numerical model outputs shown here consist of plots of the downstream variation of surface geometric mean grain size $D_{s g}$, gravel transport rate, areal fraction of alluvial coverage during floods and low flows, and grain size distributions of the gravel part of the bed load and bed surface material along the stream. Figure 8 shows a comparison of the downstream variation of gravel surface geometric mean grain size as measured in the field and predicted by the model. Note that in this river, sand sizes do not have much effect on the calculations of geometric mean grain sizes since from our field survey the volume of boulders on the river bed usually considerably outweighs the sand volume. The model results are based on two different asymptotic runs of the lateral sediment input from hillslopes: run A, spatially uniform lateral input (with $v_{d}=0.4 \mathrm{~mm} \mathrm{yr}^{-1}$ ), and run $\mathrm{B}$, linearly spatially variant lateral input (with $v_{d}=0.8 \mathrm{~mm}$ $\mathrm{yr}^{-1}$ at the upstream end and $v_{d}=0$ at the downstream end). For the most part, the numerical model results in both runs are in good agreement with the field data except the most downstream $1.5 \mathrm{~km}$ portion, which seems to be characterized by selective entrainment such that smaller sizes predominate in the load during the lower flows but the largest sizes are only moved near the peak flow. The model results in both runs (A and B) are not much different (Figure 8), which means that in this river the assumption of linearly spatially variant lateral input from the hillslopes (run B) 


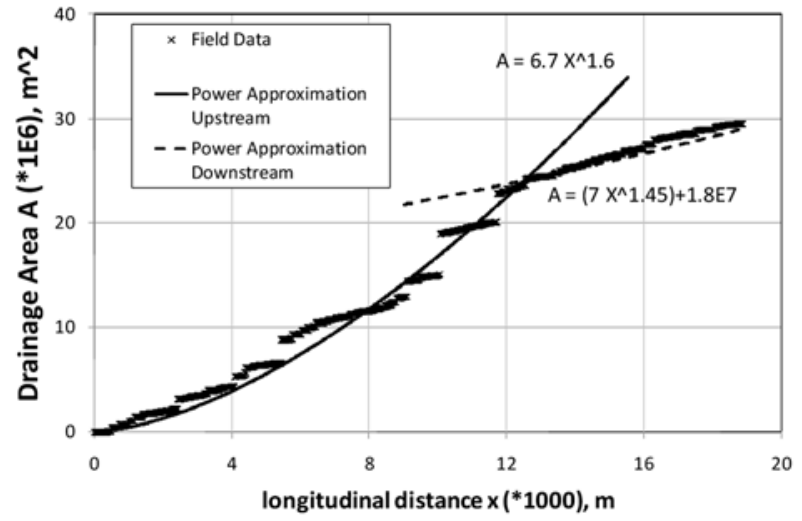

(a)

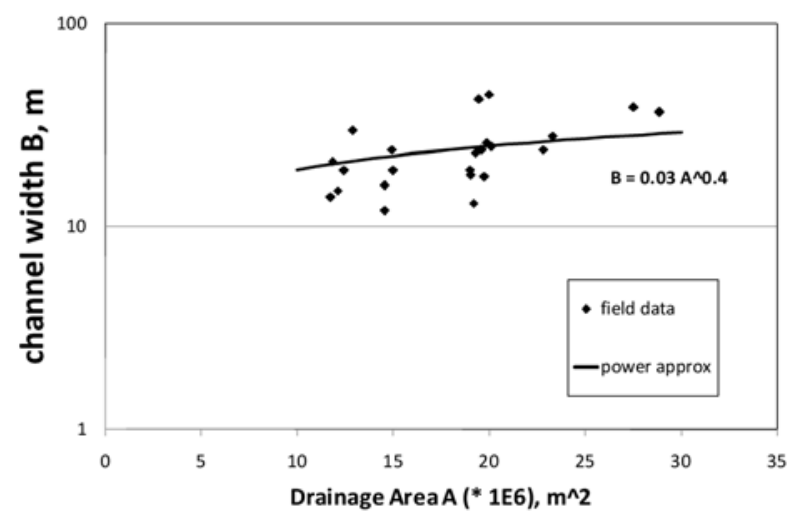

(b)

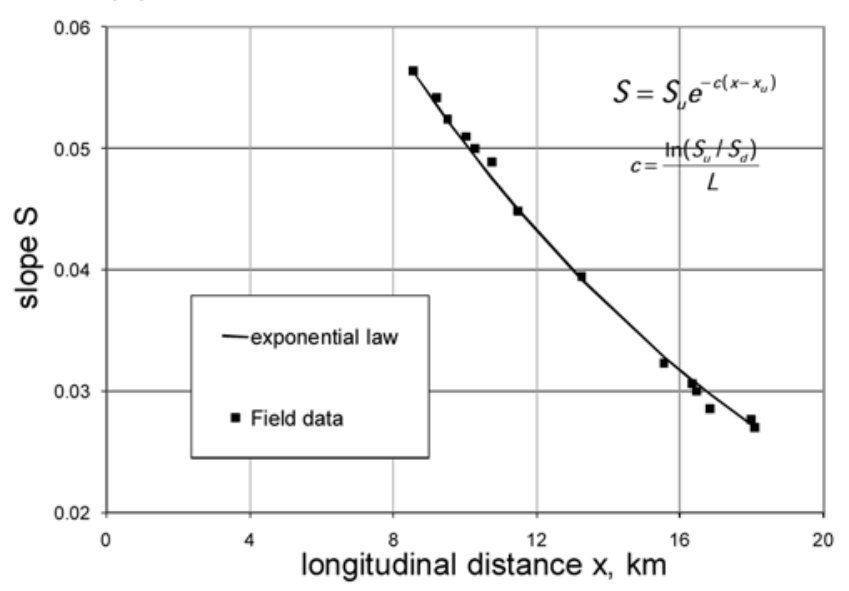

(c)

Figure 7. (a) Power approximation relating drainage area and down-channel distance for the Vieux Habitants River (coefficients adapted from Hack's law). The drainage shape in the downstream area causes the change in the power approximation. (b) Power approximation relating bedrock channel width and drainage area for the Vieux Habitants River (coefficients adapted from Montgomery and Gran [2001]). (c) Exponential approximation of channel slope along the Vieux Habitants River. should be reasonable since the lateral sediment delivery should be proportional to the lateral hillslope angle, which has been found to be steeper in the upstream area surveyed (Figure 4a). With the steeper lateral slopes in the upstream reaches, one might also expect higher lateral sediment input from debris flows or shallow landslides in these areas than the downstream counterparts.

[47] The numerical model results for the downstream variations of sediment transport rates are shown in Figure 9. Note that the model produces a large amount of sand and silt $(<2 \mathrm{~mm})$ partly because of the exclusion of particle-fracturing processes in the model. It is interesting to note, however, that sand-sized particles were observed in the field to be increasingly more common from upstream to downstream, and the river was observed to be sand bed right at its mouth. Note that there are two values required as upstream boundary in this model: volume bed load and total transport rates per unit width at the upstream end. Although exact measurements of these values is difficult to obtain, it was found that using some deviated values (e.g., 2-5 times lower or higher) of the calibrated values in Table 1 would affect the model results (particularly the sediment transport rates and the fractions of alluvial coverage) only within less than $10 \%$ of the entire reach (the most upstream part).

[48] The numerical model also produces results for the downstream variation in the areal fraction of alluvial coverage during floods and low flows for the Vieux Habitants River (Figure 10). The coverage at low flow was estimated by precipitating the wash load (sand and silt) during floods onto the bed of the stream and combining it with the gravel. The results are qualitatively consistent with our field observations that in the upstream part of the stream (e.g., upstream of the Barthole gauging station) bedrock exposures were found to be ubiquitous, whereas in the $7 \mathrm{~km}$ corresponding to the farthest downstream part of the reach bedrock exposures are absent at low flow. The results during low flows are more proper values to use even in replacement of the values during the high-flow events since the results during floods underestimate the gravel bed load sediment transport and alluvial bed coverage. In this model the neglecting of rock-splitting processes, which is implicitly built into the abrasion coefficient, results in the overproduction of silt and sand (suspended load) rather than breaking up into smaller sizes of cobble or gravel. This conclusion emphasizes the importance of developing a description of rock fracturing (comminution) in models of downstream fining in coarse bed rivers when abrasion processes dominate.

[49] The model results imply that the numerical model could be used to provide an indirect estimate of sediment transport rates during floods on the basis of the collected field data of granulometric measurements and the observation of the degree of bedrock exposure. Interestingly, Lajeunesse et al. [2009] have estimated the volume of sediment transported out of the Vieux Habitants basin on the basis of the DEM and found that approximately, bed load represents $50 \%$ of the total volume of sediment exported out of the basin, which is close to our model results (Figure 9). This aspect of the model could be useful, as it is normally difficult to directly measure sediment transport rates in bedrock streams during floods. 
Table 1. Input Parameters for the Vieux Habitants River

\begin{tabular}{|c|c|c|c|}
\hline Input Parameters & Values & Input Parameters & Values \\
\hline $\begin{array}{l}\text { Size distribution of bed load } \\
\text { at upstream end, } p_{i, u}\end{array}$ & see Figure $6 b$ & $\begin{array}{l}\text { coefficient in Manning-Strickler } \\
\text { resistance formulation, } \alpha_{r}\end{array}$ & 8.1 \\
\hline $\begin{array}{l}\text { Size distribution of lateral } \\
\text { materials from hillslopes, } p_{L i}\end{array}$ & see Figure $6 b$ & $\begin{array}{l}\text { coefficient in multiple-sized } \\
\text { gravel transport relation of Parker [1990], } \alpha_{p}\end{array}$ & 0.000135 \\
\hline Reach length, $L$ & $9.53 \mathrm{~km}$ & $\begin{array}{l}\text { coefficient in relation between } \\
\text { roughness height and } D_{s 90}, n_{k}\end{array}$ & 2.5 \\
\hline Effective rainfall rate, $i$ & $20 \mathrm{~mm} \mathrm{~h}^{-1}$ & submerged specific gravity of sediment, $R$ & 1.65 \\
\hline Channel slope at upstream end, $S_{u}$ & 0.056 & spatial step length, $d x$ & $23.825 \mathrm{~m}$ \\
\hline Channel slope at downstream end, $S_{d}$ & 0.027 & coefficient in Hack's law, $K_{h}$ & 6.7 \\
\hline $\begin{array}{l}\text { Value of } x \text { at the upstream } \\
\text { end } x_{u} ; x=0 \text { at the divide }\end{array}$ & $8.53 \mathrm{~km}$ & exponent in Hack's law, $n_{h}$ & 1.6 \\
\hline $\begin{array}{l}\text { Volume bed load transport rate } \\
\text { per unit width at the upstream end, } q_{b T, u}\end{array}$ & $0.002 \mathrm{~m}^{2} \mathrm{~s}^{-1}$ & $\begin{array}{l}\text { coefficient in relation between channel } \\
\text { width and area upstream, } \alpha_{b}\end{array}$ & 0.03 \\
\hline $\begin{array}{l}\text { Volume total transport rate } \\
\text { per unit width at the upstream end, } q_{t o t, u}\end{array}$ & $0.003 \mathrm{~m}^{2} \mathrm{~s}^{-1}$ & $\begin{array}{l}\text { exponent in relation between channel } \\
\text { width and area upstream, } n_{b}\end{array}$ & 0.4 \\
\hline Flood intermittency, $I$ & 0.0005 & $\begin{array}{l}\text { basin-averaged denudation rate, } v_{d} \\
\text { for run A }\end{array}$ & $0.4 \mathrm{~mm} \mathrm{yr}^{-1}$ \\
\hline $\begin{array}{l}\text { Volume fraction of a grain lost per unit } \\
\text { distance traveled, } \beta\end{array}$ & $0.00015 \mathrm{~m}^{-1}$ & $\begin{array}{l}\text { denudation rate at upstream end } \\
\text { for run } \mathrm{B}, v_{d, u}\end{array}$ & $0.8 \mathrm{~mm} \mathrm{yr}^{-1}$ \\
\hline
\end{tabular}

[50] The model results for the grain size distributions of the gravel-boulder portions of the bed surface and bed load material along the study reach of the Vieux Habitants River are shown in Figures 11a and 11b, respectively. The size distributions of both surface and bed load material within the channel are mostly finer than the hillslope material because of the effect of downstream fining. It is shown in section 4 that this downstream fining feature is solely due to abrasion. The results in Figures 11a and 11b, which pertain to flood flows, show that a surface armor is automatically generated by the model: the grain size distributions for the surface material along the stream are everywhere slightly coarser than the size distributions for the bed load materials.

\subsection{Sensitivity Analysis of the Model}

[51] The sensitivity analysis of the model has been conducted (Figures 12a and 12b). The parameters, to which the model results are sensitive, include abrasion coefficient $(\beta)$, denudation rate $\left(v_{d}\right)$, rainfall rate $(i)$, and flood intermittency $(I)$. However, these parameters have been estimated with some degrees of certainty in our model testing. Note that there is no major unknown variable for this testing. The

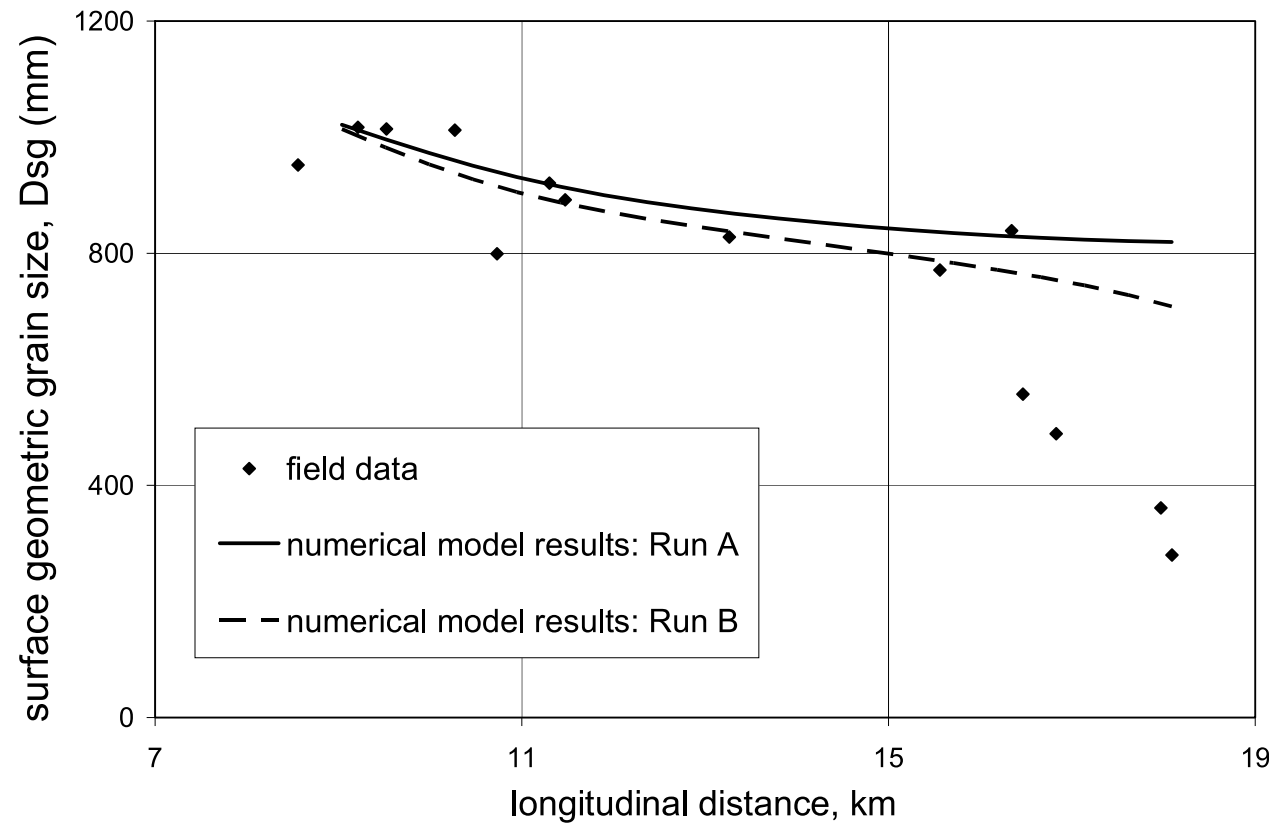

Figure 8. Comparison of the observed downstream variations of surface geometric mean grain size in the Vieux Habitants River (diamonds) and numerical model results (line). The model results are based on two different asymptotic runs of the lateral sediment input from hillslopes: run A, spatially uniform lateral input (with $v_{d}=0.4 \mathrm{~mm} \mathrm{yr}^{-1}$ ) and run B, linearly spatially variant lateral input (with $v_{d}=0.8 \mathrm{~mm} \mathrm{yr}^{-1}$ at the upstream end and $v_{d}=0$ at the downstream end). 


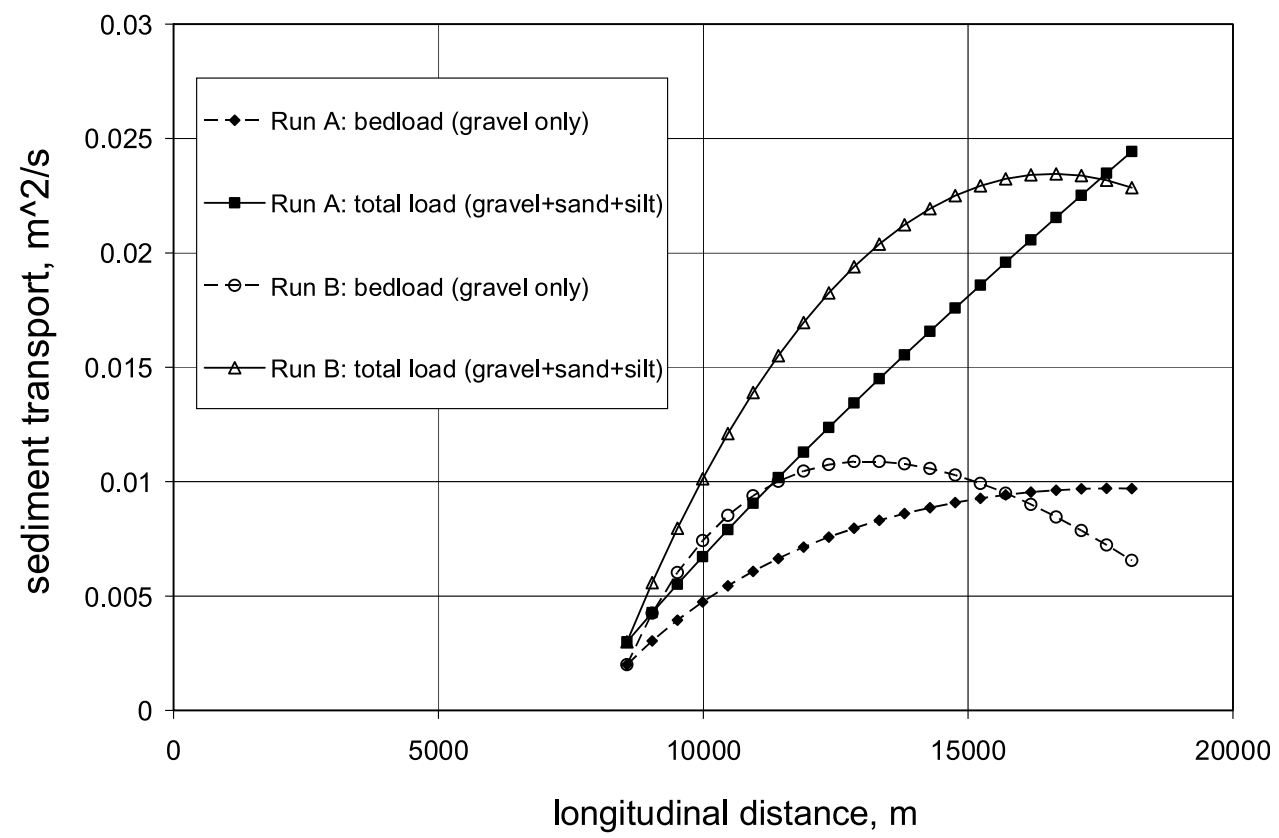

Figure 9. Numerical model results for the downstream variation of sediment transport rates predicted by the model for the Vieux Habitants River. Note that the model produces a large amount of sand and silt $(<2 \mathrm{~mm})$ partly because of the exclusion of particle-fracturing processes in the model. The model results are based on two different asymptotic runs of the lateral sediment input from hillslopes: run A, spatially uniform lateral input (with $v_{d}=0.4 \mathrm{~mm} \mathrm{yr}^{-1}$ ) and run $\mathrm{B}$, linearly spatially variant lateral input (with $v_{d}=0.8 \mathrm{~mm} \mathrm{yr}^{-1}$ at the upstream end and $v_{d}=0$ at the downstream end).

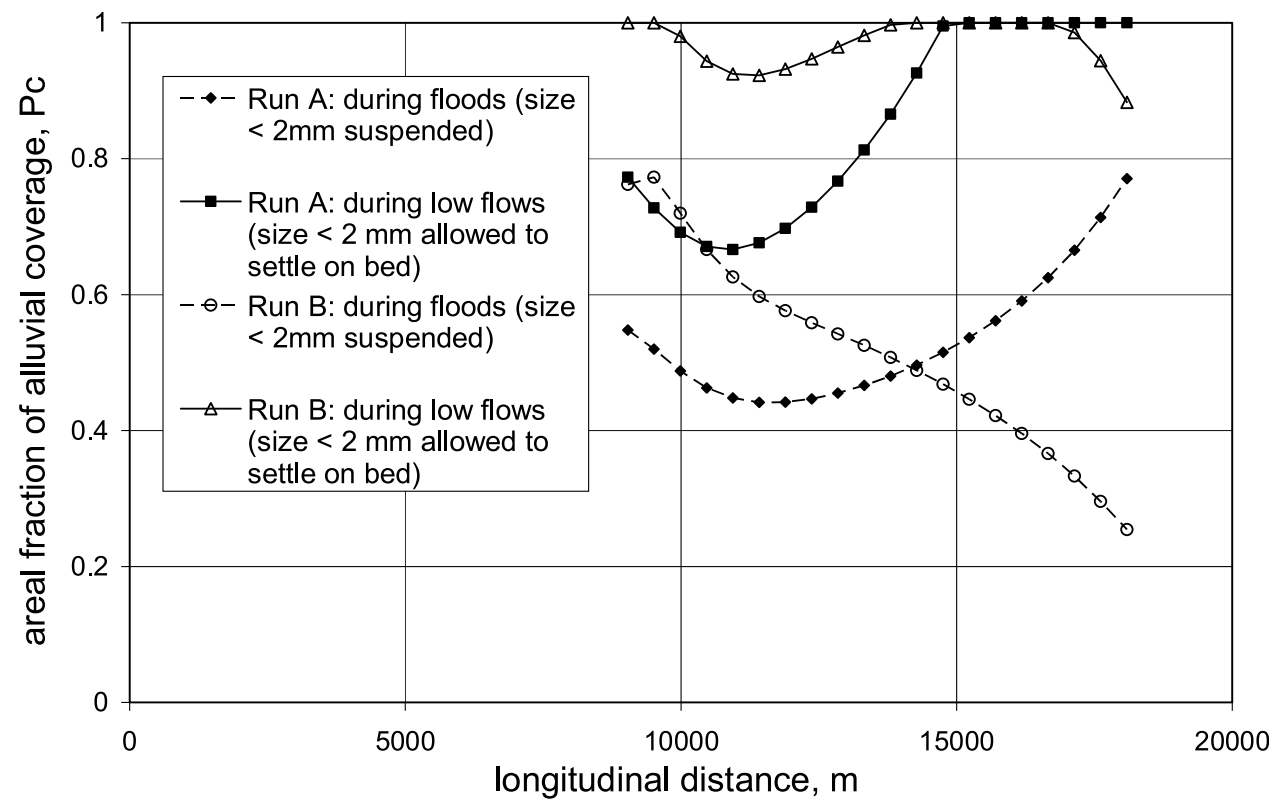

Figure 10. Numerical model results for the downstream variation of the areal fraction of alluvial coverage during floods and of low flows for the Vieux Habitants River. The results during low flow are qualitatively consistent with our field observation. The model results are based on two different asymptotic runs of the lateral sediment input from hillslopes: run A, spatially uniform lateral input (with $v_{d}=$ $0.4 \mathrm{~mm} \mathrm{yr}^{-1}$ ) and run $\mathrm{B}$, linearly spatially variant lateral input (with $v_{d}=0.8 \mathrm{~mm} \mathrm{yr}^{-1}$ at the upstream end and $v_{d}=0$ at the downstream end). 


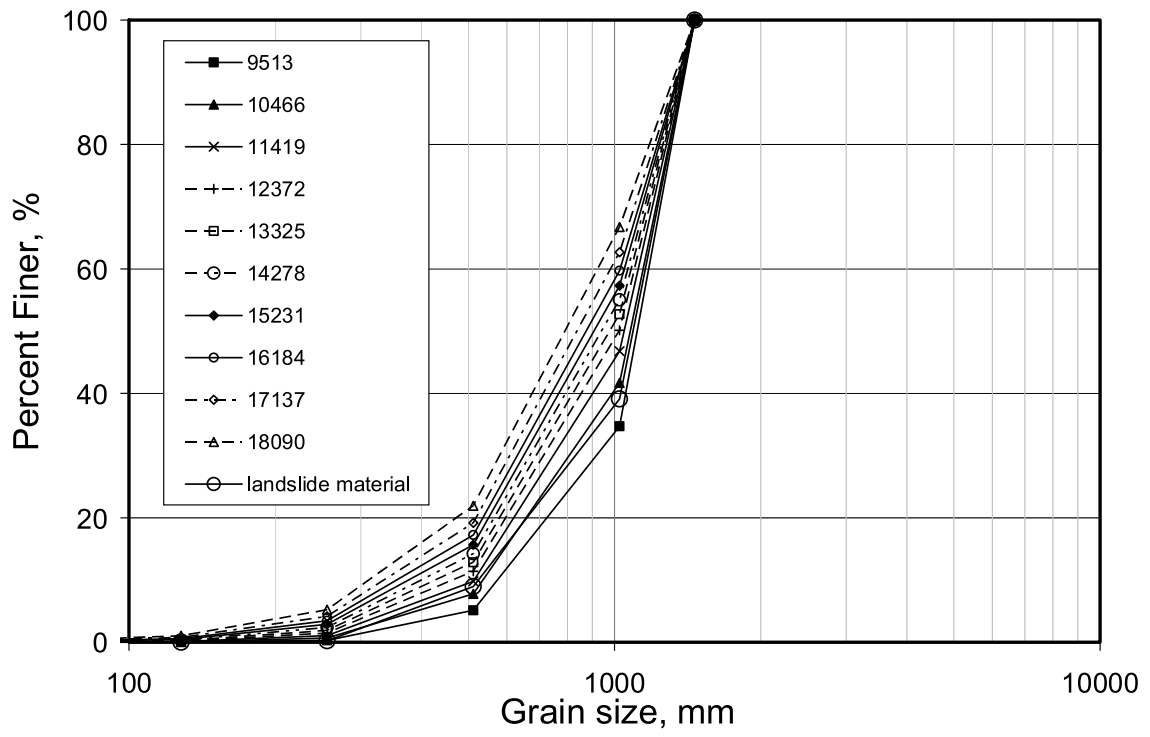

(a)

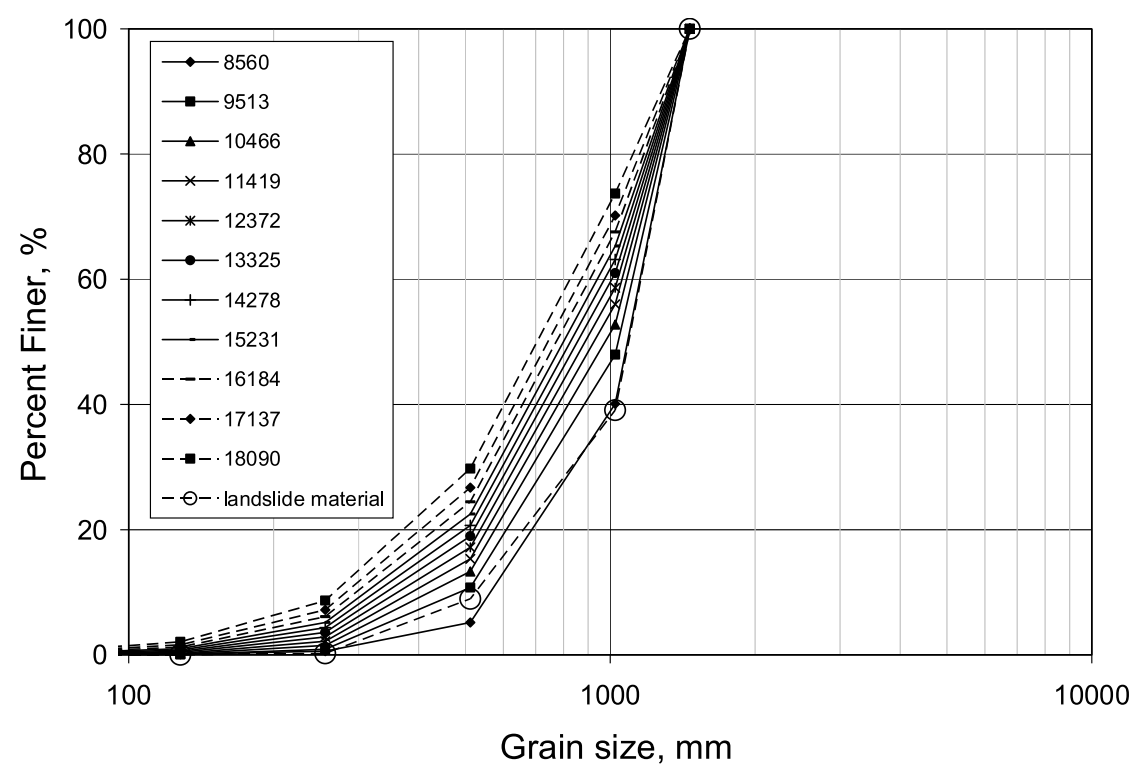

(b)

Figure 11. (a) Numerical model results for run B for grain size distributions of surface material along the Vieux Habitants River at various points downstream. (b) Corresponding numerical model results for run $\mathrm{B}$ for grain size distributions of bed load material along the Vieux Habitants River. Note that the value next to each line in the legend indicates the longitudinal distance $(\mathrm{m})$ from the upstream drainage divide. Note that the results for run A are somewhat similar to run B and thus not shown here. 


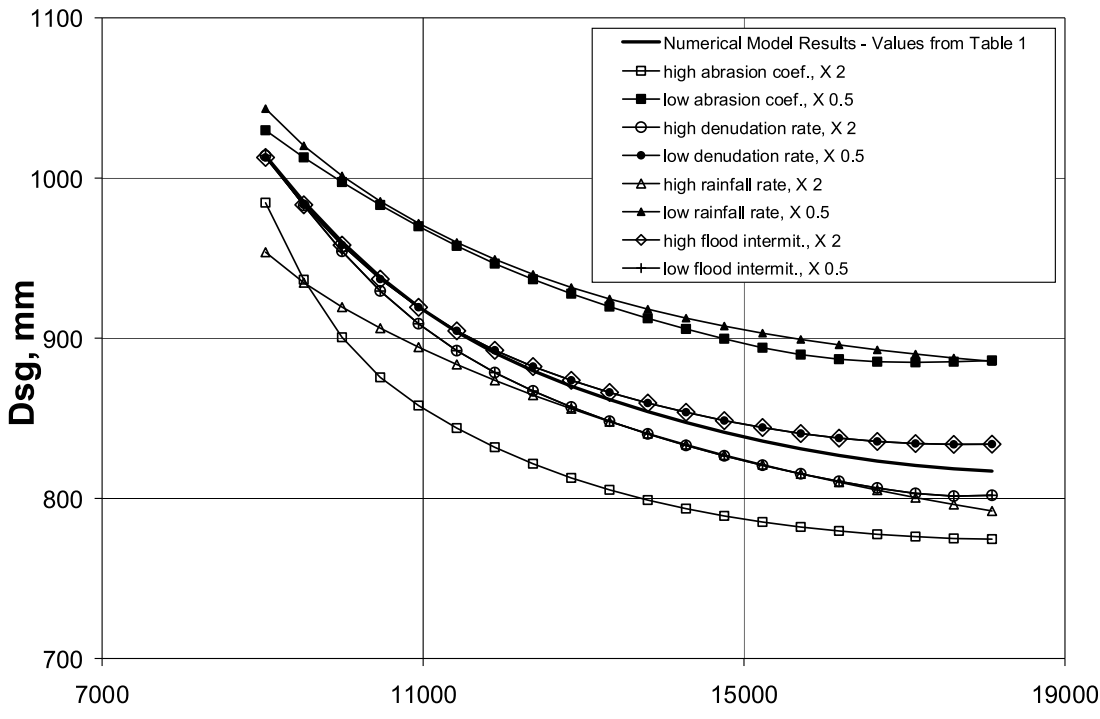

longitudinal distance, $\mathrm{m}$

(a)

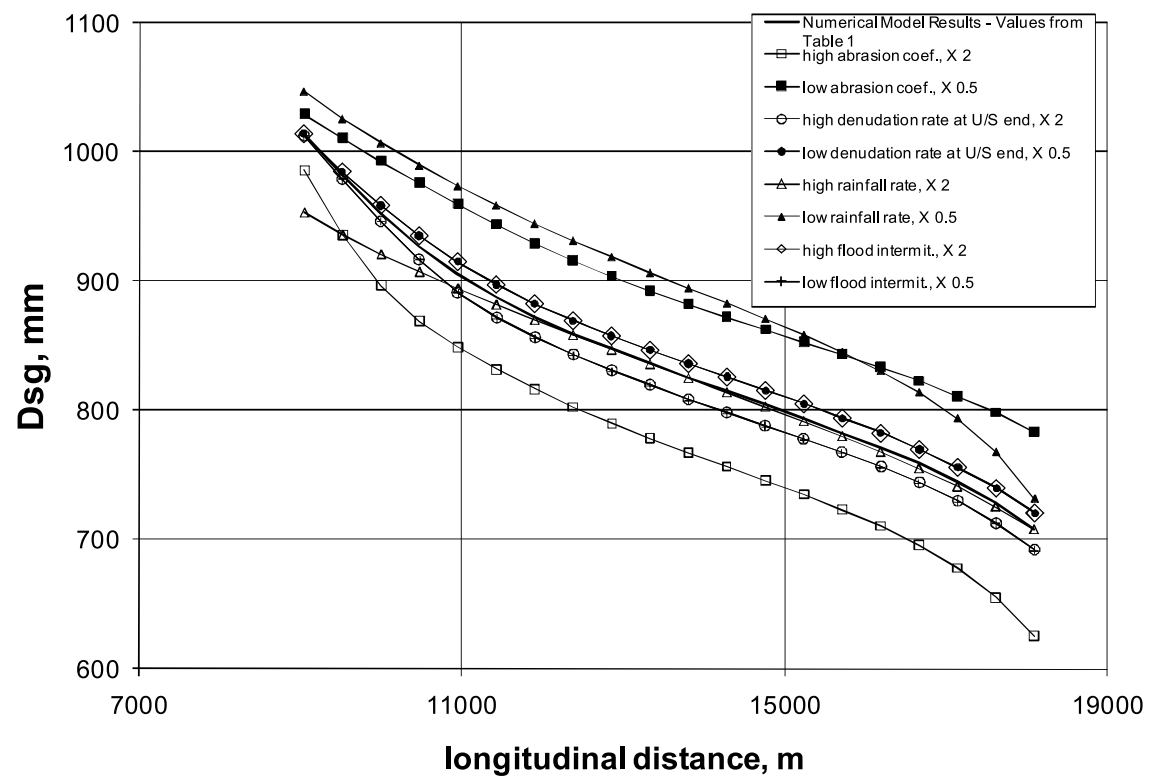

(b)

Figure 12. Sensitivity analysis of the present study model by varying the values of abrasion coefficient, basin denudation rate, rainfall rate, and flood intermittency. The values are either double or half the ones in Table 1, used to produce the model results for the Vieux Habitants River. The results are based on two different asymptotic runs of the lateral sediment input from hillslopes: (a) run A, spatially uniform lateral input (with $v_{d}=0.4 \mathrm{~mm} \mathrm{yr}^{-1}$ ) and (b) run B, linearly spatially variant lateral input (with $v_{d}=0.8 \mathrm{~mm} \mathrm{yr}^{-1}$ at the upstream end and $v_{d}=0$ at the downstream end). 


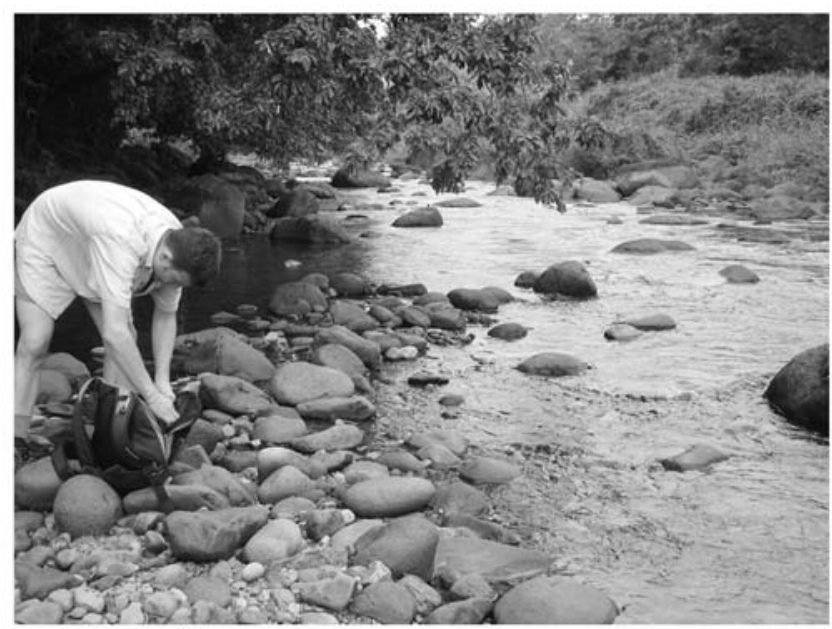

(a)

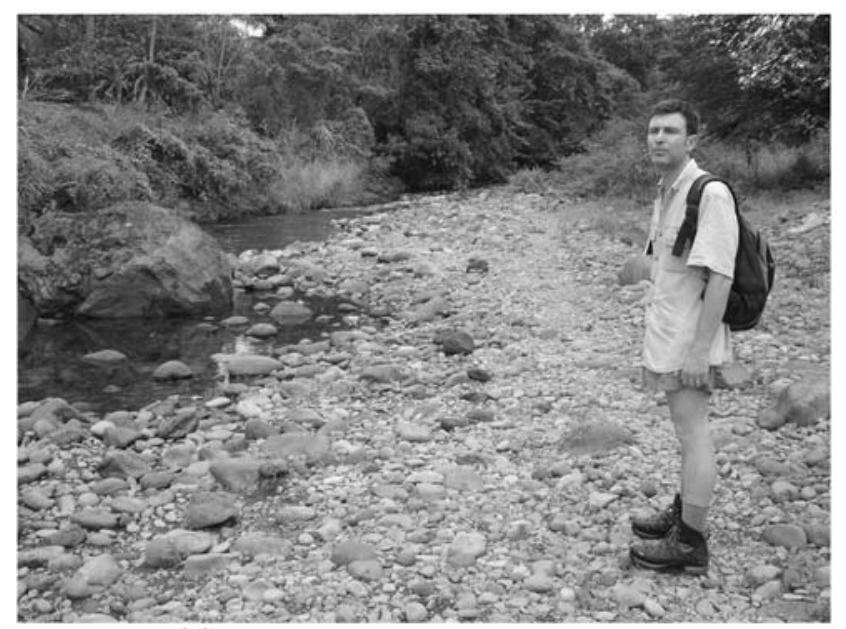

(b)

Figure 13. Abrupt change in grain sizes in Capesterre River, a nearby smaller river on Guadeloupe Island. Both pictures were taken at the same location but are different views: (a) looking upstream (notice the big boulders in the background) and (b) looking downstream. Note the drastic contrast in grain sizes. The site is about $1 \mathrm{~km}$ from the river mouth.

sensitivity analysis from both run A (Figure 12a) and run B (Figure 12b) illustrates more or less the same trend. In Figures $12 \mathrm{a}$ and $12 \mathrm{~b}$ the above parameters are either half of or double the values used in our model results (Figures 8-11) in Table 1 . The sensitivity analysis shows that in this river, among all the parameters tested, the model results are the least sensitive to the denudation rate and the flood intermittency. The model results are the most sensitive to the abrasion coefficient and the effective rainfall rate (water discharge during highest floods). Interestingly, the model results are more sensitive to the lower effective rainfall rate than the higher effective rainfall rate (Figures 12a and 12b). This is probably because the sensitivity of downstream fining of grain sizes to the effective rainfall rate or flood discharge is nonlinear.
[52] Note that parameters such as $K_{h}, n_{h}, \alpha_{b}, n_{b}, \alpha_{p}$, and $\alpha_{r}$ can be reasonably constrained with the aid of field data or are constant from empirical formula. It is not our goal here to study the sensitivity of the model to these parameters, as at this point they are best constrained by data.

\section{Discussion}

[53] In this study, we provide evidence that the physically based model of downstream fining in bedrock streams with lateral input developed is able to simulate the downstream variation in grain size characteristics of surface material along a natural bedrock river. The model provides numerical results for the downstream variations of surface geometric mean size $D_{s g}$ and surface $D_{90}$ (such that $90 \%$ by weight of a sample is finer), gravel transport rates during floods, areal fraction of alluvial coverage, transport capacity, and grain size distributions of gravel bed load and the gravel part of the bed surface material.

[54] The plot of areal fraction of alluvial coverage, which shows high bedrock exposure (i.e., low values of the fraction of alluvial coverage) in the upstream part and zero bedrock exposure in the downstream part (Figure 10), is within a reasonable range consistent with the field observations. The resulting plots of grain size characteristics along the stream are also consistent with the field data. These results of bedrock exposure would be useful when one considers the bedrock incision rate and history in a study area. Intuitively, the bedrock incision rate should depend on the degree to which the bedrock surface is exposed to the gravel in transport [e.g., Slingerland et al., 1997; Sklar and Dietrich 1998, 2004].

[55] The model results for surface geometric mean size seem to match the field data reasonably well except in a $1.5 \mathrm{~km}$ region representing the farthest downstream portion of the study reach, where the model overpredicts (Figure 8). This abrupt change in grain size is probably due to another type of selective sorting, in which smaller sizes predominate in the load during the lower flows but the largest sizes are only moved near the peak flow (so-called selective entrainment). This type of selective sorting is not considered in the present study. This abrupt change in grain sizes in the Vieux Habitants River was recorded but not documented photographically. A very similar abrupt change in grain sizes was also observed in a nearby smaller bedrock stream in the Guadeloupe Island, the Capesterre River (Figure 13). In Figure 13, boulder-sized clasts were found to be very common in the channel immediately upstream of the point at which the picture was taken, yet immediately downstream the surface material was found to abruptly change to finer gravel and cobble sizes. Material in this latter size range was continuously observed in this river from the location of Figure 13 to the river mouth, which is approximately $1 \mathrm{~km}$ downstream. A large amount of sand was observed in the bed material right at the mouth.

[56] The model can be used to quantify the relative roles of abrasion and selective sorting in downstream fining in the Vieux Habitants River. Figure 14 shows a comparison of the model results for surface geometric mean size along the channel, with a comparison between a case in which abrasion is turned off (by setting $\beta=0$ ) and one in which abrasion is included (with $\beta=0.00015 \mathrm{~m}^{-1}$ ). In the former case, the results produce essentially no grain size reduction. 


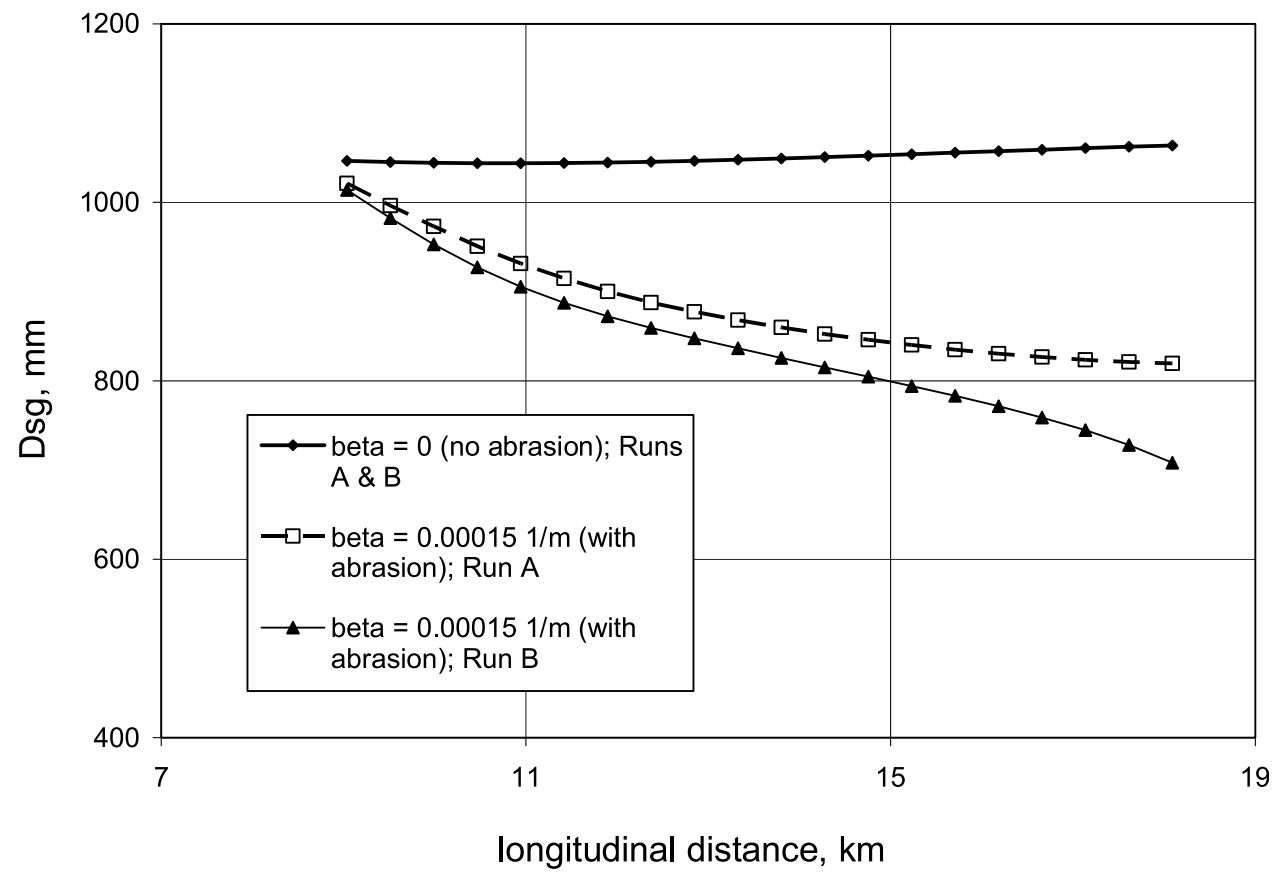

Figure 14. Model results for surface geometric mean size along the river when abrasion process is turned off $(\beta=0)$ and when abrasion process is included $\left(\beta=0.00015 \mathrm{~m}^{-1}\right)$. In the former case, the results produce no downstream fining. This means that selective sorting by differential transport may not contribute to downstream fining in the Vieux Habitants River. The model results are based on two different asymptotic runs of the lateral sediment input from hillslopes: run A, spatially uniform lateral input (with $v_{d}=0.4 \mathrm{~mm} \mathrm{yr}^{-1}$ ) and run B, linearly spatially variant lateral input (with $v_{d}=0.8 \mathrm{~mm} \mathrm{yr}^{-1}$ at the upstream end and $v_{d}=0$ at the downstream end).

This suggests that sorting by differential transport may not contribute to downstream fining in this river. However, from our modeling tests there are cases where the results show that both selective sorting and abrasion can play comparably important roles in downstream fining in bedrock streams (Figure 15). The main difference between the input parameters in this test case (Figure 15) and the ones for the Vieux Habitants River (Figure 14) is that the test case has relatively smaller grain sizes and milder slopes. In Figure 15, the results show that in the case of both selective sorting and abrasion, the surface geometric mean size is reduced in size by $32 \%$ from upstream to downstream, but in the case of selective sorting only, the surface geometric mean size is reduced by $19 \%$. This suggests that abrasion is responsible for $41 \%$ of the size reduction, and the selective sorting is responsible for the remaining 59\%.

[57] The model has a number of limitations. The application of a gravel transport relation directly to a stream in which boulders are common is unlikely to be correct in general. This is particularly true when the boulders are never inundated, even during the largest floods. Yager et al. [2007] have recently presented a methodology that could address this question. It is of interest to note that the bed load transport equation that they recommend in their calculations is that of Parker et al. [1982], which is a relative of the relation used here, i.e., that of Parker [1990]. Moreover, instead of using the concept of flood intermittency, an approach that uses an approximation of the flow duration curve to derive transport rates at different flows and integrates to generate a total transport rate could be a more effective way to investigate the interplay among the bed load transport, abrasion or fracturing, and bedrock exposure in studying downstream fining. This could be done in a future study.

[58] The model could be further improved by explicitly including fracturing (comminution) in the description of downstream fining rather than lumping it in Sternberg's law. The model as it stands produces only sand and silt from abrasion. The incorporation of fracturing would allow the breakup of coarser stones to produce finer stones as well as sand and silt. Parker et al. [2008] have presented a framework for a comminution mode that can be applied to rivers. Examples of fractured rocks commonly found in many natural bedrock rivers are shown in Figure 16. Fracturing seems to be common in many of these rivers (from our field experience, $10 \%-30 \%$ of the stones observed are so fractured in place).

[59] The model in its present form tracks sand and silt through the system by treating it as wash load during floods (as described in section 2.2.2) but precipitating it out on the bed during low flows. A more advanced treatment of sandsilt transport through a bedrock, gravel bed stream would allow for a better representation of this aspect of the modeling.

\section{Conclusion}

[60] The physically based model of downstream fining in bedrock streams with lateral input presented here defines a 


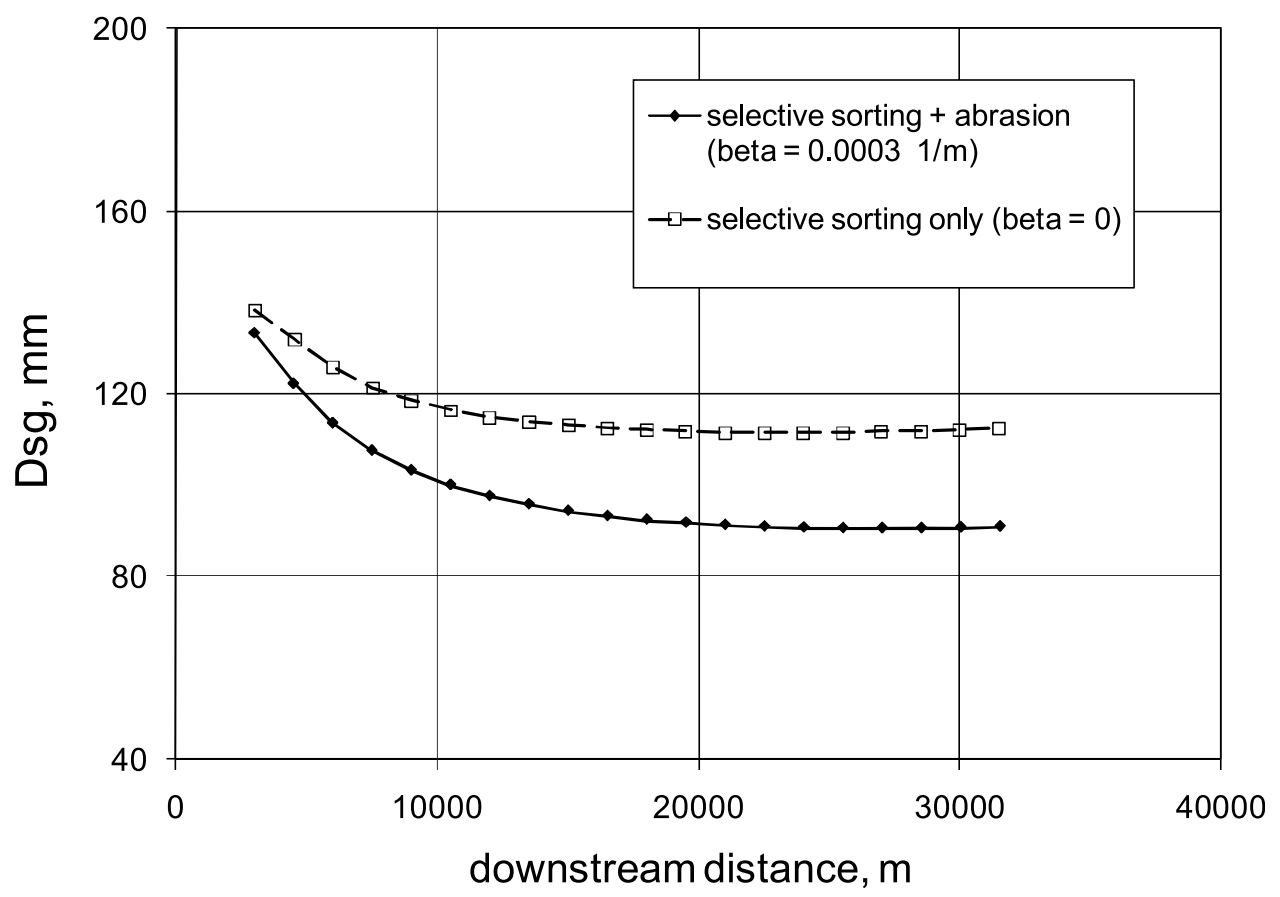

Figure 15. A test of the effect of selective sorting (differential transport) versus abrasion in downstream fining of surface material along a hypothetical stream with lower slope and smaller grain size. Contrary to the results for the Vieux Habitants River in Figure 14, where only abrasion processes were found to be responsible for the downstream fining, the test case here shows that selective sorting by differential transport could be responsible for downstream fining in bedrock streams. In this test run, $L=30 \mathrm{~km}, \beta=$ $0.0003 \mathrm{~m}^{-1}, i=20 \mathrm{~mm} \mathrm{~h}^{-1}, I=0.005, S_{u}=0.015, S_{d}=0.005, x_{u}=1.5 \mathrm{~km}, q_{b T, u}=0.002 \mathrm{~m}^{2} \mathrm{~s}^{-1}, q_{t o t, u}=$ $0.003 \mathrm{~m}^{2} \mathrm{~s}^{-1}$, basin-wide $v_{d}=2 \mathrm{~mm} \mathrm{yr}^{-1}, D_{50}=50 \mathrm{~mm}$ for bed load at the upstream end, and $D_{50}=120 \mathrm{~mm}$ for the hillslope material. Note that the grain sizes were input as probability density (not shown here) rather than the $D_{50}$ alone.

model framework for downstream fining that includes both abrasion and selective sorting by differential transport. Most parameters used in the model are physically plausible and quantifiable. To construct the model, we start by applying the concepts of probability density functions and Sternberg's law to the consideration of the abrasion terms and volume transfer rates. We then consider sediment mass conservation to derive two governing ordinary differential equations for downstream variation in bed surface and bed load grain size. We also incorporate Hack's law, a channel width relation, a simplified hydrology, sediment yield from basin-wide denudation, and the surface-based gravel transport relation for size mixture from Parker [1990] to account for the effect of selective sorting by differential transport.

[61] The numerical model results include plots of downstream variations of surface geometric mean size and surface $D_{90}$, gravel transport rates, total (gravel plus sand plus silt) transport rates, areal fraction of alluvial coverage during floods and low flows, transport capacity of sediment, and grain size distributions of bed load material and surface gravel. The model presented here is applied to field data from Vieux Habitants River, Guadeloupe Island. Using data input specifically fitted to the river, as well as reasonable estimates of other input parameters, the model is found to represent the field data fairly well. The only region where the model predictions do not fit the data is the $1.5 \mathrm{~km}$ portion of the reach farthest downstream. Within this reach, the channel slope is much milder such that another type of selective sorting, in which smaller sizes predominate in the load during the lower flows but the largest sizes are only moved near the peak flow (so-called selective entrainment), prevails.

[62] The results suggest that the model represents an advance in the study of downstream fining in bedrock streams with lateral input from hillslopes. The results further indicate that abrasion (including fracturing) is solely responsible for the downstream fining pattern over most of the study reach of the Vieux Habitants River (in which boulders are common).

[63] The model results also suggest that abrasion (including splitting) and selective sorting by differential transport can, depending on the imposed conditions, be of comparable importance for downstream fining in bedrock streams with lateral input. The model results indicate that selective sorting by differential transport is most likely to play a role in downstream fining in bedrock streams only in cases of streams with relatively small gravel sizes and lower slopes. Our work strongly suggests that future research should specifically include rock fracturing in addition to abrasion (instead of lumping them together in a Sternbergtype coefficient) in order to more realistically describe the phenomenon. 


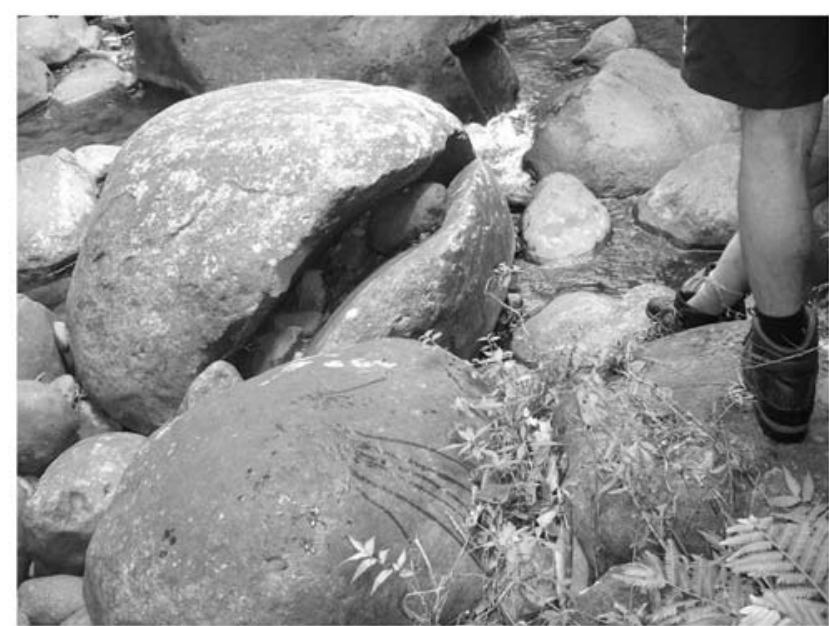

(a)

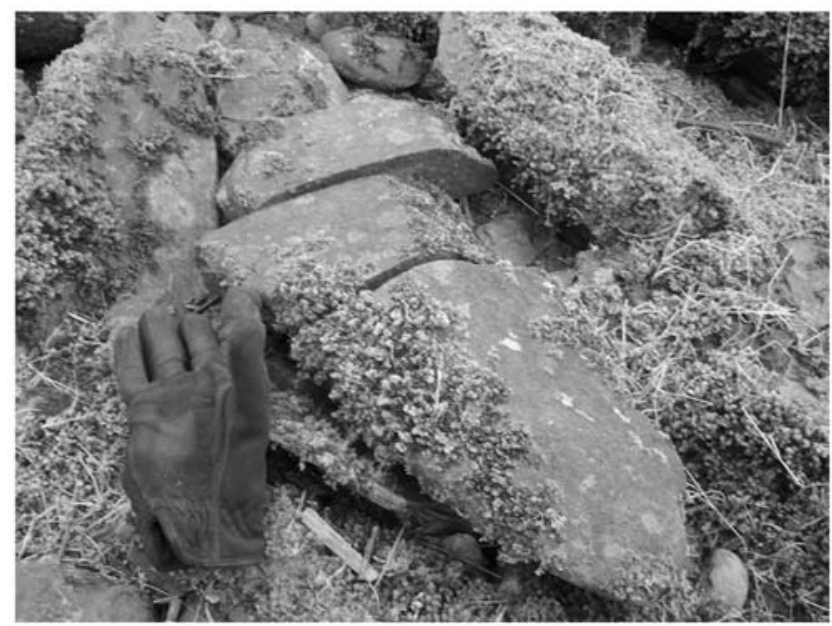

(b)

Figure 16. Examples of fractured rock commonly found in bedrock streams: (a) Bras-David River, Guadeloupe Island, and (b) South Fork Eel River, northern California, United States.

\section{Notation}

$A$ drainage area.

$A_{\text {bed }}$ volume loss density per unit bed area per unit time due to abrasion of bed particles.

$A_{\text {bed load }}$ volume loss density per unit bed area per unit time due to abrasion of bed load particles.

$A_{\text {tot }}$ total abrasion rate.

$B$ channel width.

$D$ grain size.

$D_{90}$ grain size such that $90 \%$ by volume of grains are finer.

$D_{i}$ characteristic size of the $i$ th grain size range.

$D_{o}$ grain size at the upstream end.

$D_{s 90}$ grain size in the bed surface such that $90 \%$ by volume of grains are finer.

$D_{s g}$ surface geometric mean size.

$f_{I}$ volume probability density of size $\psi$ of sediment exchanged at the interface between the surface and any substrate.
$F$ volume probability density that sediment in the surface layer is size $\psi$.

$F_{a}$ areal probability density that sediment in the bed surface layer is size $\psi$.

$F_{a i}$ areal probability density that sediment in the bed surface layer is size $\psi_{i}$.

$F_{i}$ volume probability density that sediment in the surface layer is size $\psi_{i}$.

$g$ gravitational acceleration.

$G_{i}$ grain size-specific function in gravel transport relation of Parker [1990].

$i$ effective rainfall rate.

$I$ flood intermittency.

$I_{L T}$ volume input of sediment of all sizes per unit distance downstream per unit time.

$K_{h}$ coefficient in Hack's law.

$L$ total length of the study reach.

$L_{a}$ thickness of the active layer.

$n_{b}$ exponent in width-area relation.

$n_{h}$ exponent in Hack's law.

$n_{k}$ coefficient characterizing surface roughness $(\sim 1.5-3)$.

$N$ total number of grain sizes.

$p$ volume probability density that a bed load particle is size $\psi$.

$p_{i}$ volume probability density that a bed load particle is size $\psi_{i}$.

$P_{c}$ fraction of bedrock surface that is covered by alluvium.

$p_{L}$ volume probability density of sediment in hillslope material derived from adjacent hillslopes.

$p_{L i}$ volume probability density of sediment in hillslope material derived from adjacent hillslopes for the $i$ th grain size range.

$q_{b d}$ density of volume bed load transport rate per unit width of grain size $\psi$.

$q_{b T}$ total volume bed load transport rate per unit width summed over all grain sizes.

$q_{b T c}$ capacity transport rate of gravel.

$R$ gravel submerged specific gravity.

$S$ channel slope.

$S_{d}$ bed slope at the downstream boundary of the study reach.

$S_{u}$ bed slope at the upstream boundary of the study reach.

$t$ time.

$T_{\text {bed }}$ volume transfer rate per unit time per unit bed area of bed particles through $\psi$ space.

$T_{\text {bed load }}$ volume transfer rate per unit time per unit bed area, or flux, through $\psi$ space of bed load sediment.

$T_{\text {tot }}$ total transfer rate per unit bed area per unit time.

$u *$ shear velocity.

$\hat{u}$ alternative form of shear velocity excluding grain size.

$v_{b}$ velocity of bed load particle of size $\psi$.

$v_{d}$ an estimate of the denudation rate of the hillslopes.

$V_{p}$ grain volume.

$x$ down-channel distance.

$x_{u}$ distance from the upstream divide to the upstream boundary of the study reach 
$\alpha$ abrasion coefficient in Sternberg's law (equal to $\beta / 3)$.

$\alpha_{b}$ coefficient in width-area relation.

$\alpha_{p}$ constant in gravel transport relation of Parker [1990].

$\alpha_{r}$ coefficient in the Manning-Strickler resistance relation.

$\beta$ abrasion coefficient characterizing the fraction volume of a grain that is lost per unit distance traveled.

$\eta$ bed elevation.

$\lambda_{p}$ bed porosity.

$\xi_{b d}$ volume density per unit bed area of bed load particles in motion of size $\psi$.

$\psi$ logarithmic grain size.

$\psi_{i}$ logarithmic grain size of the $i$ th grain size range.

$\bar{\psi}_{s}$ surface arithmetic mean size.

$\sigma_{s}$ surface arithmetic standard deviation.

$\sigma_{s g}$ surface geometric standard deviation.

[64] Acknowledgments. This theoretical modeling work was supported by the National Center for Earth-surface Dynamics (NCED), a Science and Technology Center of the U.S. National Science Foundation, funded under agreement EAR-0120914. The field work and model application represent a joint effort by teams from France and the United States. They were supported by two organizations: the Programme Reliefs de la Terre (INSU), France, and the NCED. We thank Céline Dessert, François Beauducel, and the whole team of the Volcanic Observatory of Guadeloupe and the Parc National de la Soufrière de Guadeloupe for their help and support. We also thank Paul Planton and Pierre Valla, who participated in the granulometric measurements. We are indebted to Martial Pellegrinelli and the Direction Régionale de L'Evironnement, who provided us with the hydrographic data. In addition, the reviews by Greg Pasternack, Nicole Gasparini, and two anonymous reviewers are greatly appreciated.

\section{References}

Blanc, F. (1983), Corrélations chronologiques et géochimiques des formations volcaniques du sud de la Basse-Terre de Guadeloupe (Petites Antilles), début du cycle récent, Ph.D. thesis, 171 pp., Univ. Sci. Medic Grenoble, Grenoble, France.

Bradley, W. C. (1970), Effect of weathering on abrasion of granitic gravel, Colorado River, Texas, Geol. Soc. Am. Bull., 81, 61-80, doi:10.1130/ 0016-7606(1970)81[61:EOWOAO]2.0.CO;2.

Carlut, J., and X. Quidelleur (2000), Absolute paleointensities recorded during the Brunhes chron at La Guadeloupe Island, Phys. Earth Planet. Inter., 120, 255-269, doi:10.1016/S0031-9201(99)00170-3.

Carlut, J., X. Quidelleur, V. Courtillot, and G. Boudon (2000), Paleomagnetic directions and $\mathrm{K} / \mathrm{Ar}$ dating of 0 to $1 \mathrm{Ma}$ lava flows from La Guadeloupe Island (French West Indies): Implications for time-averaged field models, J. Geophys. Res., 105(B1), 835-849, doi:10.1029/ 1999JB900238.

Chatanantavet, P. (2007), Physically based models of bedrock incision processes in mountain streams, Ph.D. dissertation, 210 pp., Univ. of Minn, Minneapolis.

Chatanantavet, P., and G. Parker (2008), Experimental study of bedrock channel alluviation under varied sediment supply and hydraulic conditions, Water Resour. Res., 44, W12446, doi:10.1029/2007WR006581.

Chatanantavet, P., and G. Parker (2009), Physically based modeling of bedrock incision by abrasion, plucking, and macroabrasion, J. Geophys. Res., 114, F04018, doi:10.1029/2008JF001044.

Cui, Y., G. Parker, and C. Paola (1996), Numerical simulation of aggradation and downstream fining, J. Hydraul. Res., 34(2), 185-214.

Ferguson, R., T. Hoey, S. Wathen, and A. Werritty (1996), Field evidence of rapid downstream fining of river gravels through selective transport, Geology, 24(2), 179-182, doi:10.1130/0091-7613(1996)024<0179: FEFRDF $>2.3 . \mathrm{CO} ; 2$.

Feuillet, N., I. Manighetti, and P. Tapponier (2001), Active arc-transverse normal faulting in Guadeloupe (French Lesser Antilles), C. R. Acad. Sci., Ser. IIA, 333, 583-590, doi:10.1016/S1251-8050(01)01543-9.

Feuillet, N., P. Tapponnier, and I. Manighetti (2004), Differential uplift and tilt of Pleistocene reef platforms and Quaternary slip rate on the Morne-
Piton normal fault (Guadeloupe, French West Indies), J. Geophys. Res., 109, B02404, doi:10.1029/2003JB002496.

Gasparini, N. M., G. E. Tucker, and R. L. Bras (1999), Downstream fining through selective particle sorting in an equilibrium drainage network, Geology, 27(12), 1079-1082, doi:10.1130/0091-7613(1999)027<1079: DFTSPS $>2.3 . \mathrm{CO} ; 2$.

Gasparini, N. M., G. E. Tucker, and R. L. Bras (2004), Network-scale dynamics of grain-size sorting: Implications for downstream fining, stream-profile concavity, and drainage basin morphology, Earth Surf. Processes Landforms, 29, 401-421, doi:10.1002/esp.1031.

Gomez, V., B. J. Rosser, D. H. Peacock, D. M. Hicks, and J. A. Palmer (2001), Downstream fining in a rapidly aggrading gravel bed river, $\mathrm{Wa}$ ter Resour. Res., 37(6), 1813-1823, doi:10.1029/2001WR900007.

Hack, J. T. (1957), Studies of longitudinal stream profiles in Virginia and Maryland, U.S. Geol. Surv. Prof. Pap., 294-B, 45-97.

Hirano, M. (1971), River bed degradation with armoring, Proc. Jpn. Soc. Civ. Eng., 195, 55-65.

Hoey, T. B., and R. Ferguson (1994), Numerical simulation of downstream fining by selective transport in gravel bed rivers: Model development and illustration, Water Resour. Res., 30(7), 2251-2260, doi:10.1029/ 94WR00556.

Kellerhals, R., and D. I. Bray (1971), Sampling procedures for coarse fluvial sediments, J. Hydraul. Div. Am. Soc. Civ. Eng., 97(HY8), 11651180.

Knighton, A. D. (1984), Fluvial Forms and Processes, 218 pp., Edward Arnold, London.

Kodama, Y. (1994a), Downstream changes in the lithology and grain-size of fluvial gravels, the Watarase River, Japan: Evidence of the role of downstream fining, J. Sediment. Res., Sect. A, 64, 68-75.

Kodama, Y. (1994b), Experimental study of abrasion and its role in producing downstream fining in gravel-bed rivers, J. Sediment. Res., Sect. A, $64,76-85$.

Komorowski, J. C., G. Boudon, M. Semet, F. Beauducel, C. Anténor-Balzac, S. Bazin, and G. Hammouya (2005), Guadeloupe, in Volcanic Atlas of the Lesser Antilles, edited by S. R. Unit, pp. 65-102, Univ. of the West Indies, Saint Augustine, Trinidad and Tobago.

Krumbein, W. C. (1941), The effects of abrasion on the size, shape, and roundness of rock fragments, J. Geol., 49, 482-520, doi:10.1086/ 624985.

Kuenen, P. H. (1956), Experimental abrasion of pebbles 2. Rolling by current, J. Geol., 64, 336-368, doi:10.1086/626370.

Lajeunesse, E., C. Delacourt, C. Dessert, P. Allemand, P. Grandjean, and F. Beauducel (2009), Denudation rates of a tropical volcanic Island: Basse Terre, Guadeloupe archipelago, Lesser Antilles Arc, internal memorandum, 11 pp., Lab. de Dyn. des Fluides Geol., Inst. de Phys. du Globe de Paris, Paris.

Montgomery, D. R., and K. B. Gran (2001), Downstream variations in the width of bedrock channels, Water Resour. Res., 37(6), 1841-1846, doi:10.1029/2000WR900393.

Paola, C., G. Parker, R. Seal, S. K. Sinha, J. B. Southard, and P. R. Wilcock (1992), Downstream fining by selective deposition in a laboratory flume, Science, 258, 1757-1760, doi:10.1126/science.258.5089.1757.

Parker, G. (1990), Surface-based bedload transport relation for gravel rivers, J. Hydraul. Res., 28(4), 417-436.

Parker, G. (1991a), Selective sorting and abrasion of river gravel I: Theory, J. Hydraul. Eng., 117(2), 131-149, doi:10.1061/(ASCE)0733-9429 (1991)117:2(131).

Parker, G. (1991b), Selective sorting and abrasion of river gravel II: Applications, J. Hydraul. Eng., 117(2), 150-171, doi:10.1061/(ASCE)07339429(1991)117:2(150).

Parker, G. (1992), Some random notes on grain sorting, in Proceedings of the International Grain Sorting Seminar, October, 1991, Ascona, Switzerland, edited by D. Vischer, pp. 19-76, Mitt. der Vers. fuer Wasserbau, Zurich, Switzerland.

Parker, G. (2004), Review of 1-D open channel hydraulics, in $1 D$ Sediment Transport Morphodynamics With Applications to Rivers and Turbidity Currents [electronic], chap. 5, Univ. of Ill. at Urbana-Champaign, Urbana. (Available at http://vtchl.uiuc.edu/people/parkerg/morphodynamics_ e-book.htm)

Parker, G., P. Klingeman, and D. McLean (1982), Bedload and size distribution in natural paved gravel bed streams, J. Hydraul. Eng., 108(4), 544-571.

Parker, G., V. Voller, C. Paola, K. Hill, L. S. Sklar, and W. E. Dietrich (2008), Comminution as a mechanism for downstream fining, paper presented at River Flow 2008 Conference, Çeşme, Turkey, 3-5 Sept. 
Pizzuto, J. E. (1995), Downstream fining in a network of gravel-bedded rivers, Water Resour. Res., 31(3), 753-759, doi:10.1029/94WR02532.

Rad, S., P. Louvat, C. Gorge, J. Gaillardet, and C. Allegre (2006), River dissolved and solid loads in the Lesser Antilles: New insight into basalt weathering processes, J. Geochem. Explor., 88, 308-312, doi:10.1016/j. gexplo.2005.08.063

Rahuel, J. L., F. M. Holly, J. P. Chollet, P. J. Belleudy, and G. Yang (1989), Modeling of river bed evolution for bedload sediment mixtures, J. Hydraul. Eng., 115(11), 1521-1542, doi:10.1061/(ASCE)07339429(1989)115:11(1521).

Rana, S. A., D. B. Simons, and K. Mahmood (1973), Analysis of sediment sorting in alluvial channels, J. Hydraul. Div. Am. Soc. Civ. Eng., 99(11), 1967-1980.

Rice, S. P. (1994), Towards a model of changes in bed material texture at the drainage basin scale, in Process Models and Theoretical Geomorphology, edited by M. J. Kirkby, pp. 159-172, John Wiley, New York.

Samper, A., A. X. Quidelleur, P. Lahitte, and M. Mollex (2007), Timing of effusive volcanism and collapse events within an oceanic arc island: Basse-Terre, Guadeloupe archipelago (Lesser Antilles Arc), Earth Planet. Sci. Lett., 258, 175-191, doi:10.1016/j.eps1.2007.03.030.

Seal, R., and C. Paola (1995), Observations of downstream fining on the North Fork Toutle River near Mount St. Helens, Washington, Water Resour. Res., 31(5), 1409-1419, doi:10.1029/94WR02976.

Sklar, L. S., and W. E. Dietrich (1998), River longitudinal profiles and bedrock incision models: Stream power and the influence of sediment supply, in Rivers Over Rock: Fluvial Processes in Bedrock Channels, Geophys. Monogr. Ser., vol. 107, edited by K. Tinkler and E. E. Wohl, pp. 237-260, AGU, Washington, D. C.

Sklar, L. S., and W. E. Dietrich (2001), Sediment and rock strength controls on river incision into bedrock, Geology, 29(12), 1087-1090, doi:10.1130/0091-7613(2001)029<1087:SARSCO >2.0.CO;2

Sklar, L. S., and W. E. Dietrich (2004), A mechanistic model for river incision into bedrock by saltating bed load, Water Resour. Res., 40, W06301, doi:10.1029/2003WR002496.

Sklar, L. S., W. E. Dietrich, E. Foufoula-Georgiou, B. Lashermes, and D. Bellugi (2006), Do gravel-bed river size distributions record chan- nel network structure?, Water Resour. Res., 42, W06D18, doi:10.1029/2006WR005035.

Slingerland, R., S. D. Willett, and H. L. Hennessey (1997), A new fluvial bedrock incision model based on the work-energy principle, Eos Trans. $A G U, 78(46)$, Fall Meet. Suppl., Abstract H42F-12.

Sternberg, H. (1875), Untersuchungen über längen- und querprofil geschiebeführender Flüss, Z. Bauwesen, 25, 483-506.

van Niekerk, A., K. R. Vogel, R. L. Slingerland, and J. S. Bridge (1992), Routing of heterogeneous sediments over movable bed: Model development, J. Hydraul. Eng., 118(2), 246-261, doi:10.1061/(ASCE) 0733-9429(1992)118:2(246).

Wilcock, P. R., and J. C. Crowe (2003), Surface-based transport model for mixed-size sediment, J. Hydraul. Eng., 129(2), 120-128, doi:10.1061/(ASCE)0733-9429(2003)129:2(120).

Wolman, M. G. (1954), A method of sampling coarse river bed material, Eos Trans. $A G U, 35(6), 951$.

Wyrick, J. R., and G. B. Pasternack (2008), Modeling energy dissipation and hydraulic jump regime responses to channel nonuniformity at river steps, J. Geophys. Res., 113, F03003, doi:10.1029/2007JF000873.

Yager, E. M., J. W. Kirchner, and W. E. Dietrich (2007), Calculating bed load transport in steep boulder bed channels, Water Resour. Res., 43, W07418, doi:10.1029/2006WR005432.

P. Chatanantavet, School of Earth and Space Exploration, Arizona State University, PO Box 871404,Tempe, AZ 85287-1404, USA. (pchatana@, mainex1.asu.edu)

E. Lajeunesse and L. Malverti, Laboratoire de Dynamique des Fluides Géologiques, Institut de Physique du Globe de Paris, 4 P1. Jussieu, F-75005 Paris, France.

P. Meunier, Department of Earth Sciences, University of Cambridge, Cambridge CB2 3EQ, UK.

G. Parker, Department of Civil and Environmental Engineering, University of Illinois at Urbana-Champaign, Urbana, IL 61801, USA. 